\title{
Changes in the Substrate Source Reveal Novel Interactions in the Sediment-Derived Methanogenic Microbial Community
}

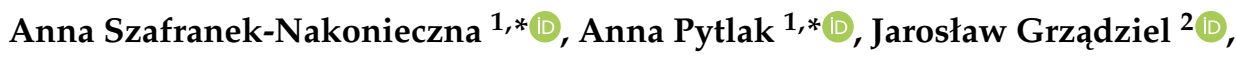 \\ Adam Kubaczyński ${ }^{3}$, Artur Banach ${ }^{1}{ }^{\mathbb{D}}$, Andrzej Górski ${ }^{1}$, Weronika Goraj ${ }^{1}$, \\ Agnieszka Kuźniar ${ }^{1}$, Anna Gałązka ${ }^{2}$ and Zofia Stępniewska ${ }^{1}$ \\ 1 Department of Biochemistry and Environmental Chemistry, Institute of Biotechnology, The John Paul II \\ Catholic University of Lublin, Konstantynów Street 1 I, 20-708 Lublin, Poland \\ 2 Department of Agricultural Microbiology, Institute of Soil Science and Plant Cultivation-State Research \\ Institute (IUNG-PIB), Czartoryskich Street 8, 24-100 Puławy, Poland \\ 3 Institute of Agrophysics, Polish Academy of Sciences, Doświadczalna Street 4, 20-290 Lublin, Poland \\ * Correspondence: anna.szafranek@kul.pl (A.S.-N.); apytlak@kul.pl (A.P.); \\ Tel.: +48-81-454-54-60 (A.S.-N.); +48-81-454-54-61 (A.P.)
}

Received: 15 July 2019; Accepted: 6 September 2019; Published: 8 September 2019

\begin{abstract}
Methanogenesis occurs in many natural environments and is used in biotechnology for biogas production. The efficiency of methane production depends on the microbiome structure that determines interspecies electron transfer. In this research, the microbial community retrieved from mining subsidence reservoir sediment was used to establish enrichment cultures on media containing different carbon sources (tryptone, yeast extract, acetate, $\mathrm{CO}_{2} / \mathrm{H}_{2}$ ). The microbiome composition and methane production rate of the cultures were screened as a function of the substrate and transition stage. The relationships between the microorganisms involved in methane formation were the major focus of this study. Methanogenic consortia were identified by next generation sequencing (NGS) and functional genes connected with organic matter transformation were predicted using the PICRUSt approach and annotated in the KEGG. The methane production rate (exceeding $12.8 \mathrm{mg} \mathrm{CH}_{4} \mathrm{~L}^{-1} \mathrm{~d}^{-1}$ ) was highest in the culture grown with tryptone, yeast extract, and $\mathrm{CO}_{2} / \mathrm{H}_{2}$. The analysis of communities that developed on various carbon sources casts new light on the ecophysiology of the recently described bacterial phylum Caldiserica and methanogenic Archaea representing the genera Methanomassiliicoccus and Methanothrix. Furthermore, it is hypothesized that representatives of Caldiserica may support hydrogenotrophic methanogenesis.
\end{abstract}

Keywords: methanogenesis; bottom sediments; enrichment culture; Caldiserica; Methanothrix; Methanomassiliicoccus

\section{Introduction}

Microbial diversity and functioning in the environment are one of the most intriguing issues in science, given that they are related to the foundations of the knowledge regarding biogeochemical cycles. Recent methodical advances, in particular the introduction of next generation sequencing, facilitate the description of microbiomes with unprecedented depth [1,2]. It is very important to recognize microbial communities in the natural environment in terms of their composition and function, as achievements in this field not only contribute to overall knowledge but also provide a basis for biotechnological progress [3,4]. One of the most common objects of this type of research are anoxic environments, which are a source of microbiota that can be employed in biogas production due to their physiological capabilities $[5,6]$. Methanogenesis is a multistage process in which degradation 
of complex organic molecules into simple one-carbon compounds is performed by a consortium of microorganisms $[7,8]$. Their existence in the natural environment is an effect of coevolution leading to the development of metabolic interactions that allow the flow of carbon, energy, and other intermediates for mutual benefit $[9,10]$. The best recognized methanogenic Archaea belong to the phylum Euryarchaeota and are classified into seven orders, namely Methanococcales, Methanobacteriales, Methanosarcinales, Methanomicrobiales, Methanopyrales, Methanocellales, and Methanomassiliicoccales [11]; yet, additional new phyla, namely Bathyarchaeota [12] and Verstraetearchaeota [13], have been postulated. Methanogens use a narrow range of substrates such as $\mathrm{H}_{2} / \mathrm{CO}_{2}$, formate, acetate, methanol, methylated compounds, and CO. Ethanol and 2-propanol may be used by some methanogens instead of $\mathrm{H}_{2}$ as electron donors [11]. This narrow range of substrates is delivered by bacteria, mostly from the genera Clostridium, Pseudomonas, Desulfovibrio, and Cellulomonas [14]. Organic matter, in freshwater lakes, is primarily decomposed by bacteria to acetate, $\mathrm{CO}_{2}$, and $\mathrm{H}_{2}$, which are the main substrates used by methanogens in two major pathways: hydrogenotrophic and acetotrophic $[15,16]$.

The biotechnological potential of anaerobic microbial communities is closely connected with their biodiversity [17]. The highest biodiversity has been found in transitional zones called ecotones [18]. The observations that were first made on the macroscale (for higher plants and animals) [19] revealed the highest biodiversity at the boundaries of forests and meadows [20], or lakes and terrestrial ecosystems [21], and have been confirmed on the microscale as well [22]. Microbial biodiversity (in terms of the structure and function) in zones located between forests and grasslands [22], lakes and rivers $[23,24]$, was found to be higher than in adjacent ecosystems. Such locations may thus have a hidden potential for biotechnology. The present study was focused on a microbial community found in the sediment of a shallow reservoir, Szczecin, that has developed over the last three decades in subsidence resulting from mining activity. Due to the continuous exploitation of coal, the area and depth of the reservoir are increasing continuously. It is also exposed to huge temperature and insolation fluctuations resulting from the climatic conditions of the mid latitudes. Consequently, the sediment is subjected to continuous changes in temperature and aeration. Furthermore, the submergence of subsequent fragments of agricultural soils leads to the release of huge amounts of biogenic compounds, and an additional portion thereof is transported from adjacent fields by surface runoff. The imbalance in the ecosystem is manifested by algal blooms occurring in the reservoir each summer. Oxygen deficiencies and organic matter supply from decaying algae create conditions that support biogenic methane $\left(\mathrm{CH}_{4}\right)$ formation, which is a result of the cooperation of methanogens with fermentative microorganisms.

Generally, the biodiversity and metabolic activities of bacterial communities in lake sediments decrease with the depth in the profile [25]. Hence, the surface layer of the bottom sediments of the Szczecin reservoir was chosen to study microbial ecology and a possible source of microorganisms that can potentially be used in biogas production.

Sediment-derived enrichment cultures grown on various carbon substrates were used as a tool to elucidate the relationship between microbial community composition and methane production rate. Cultivation largely reduces the initial biodiversity. On the other hand, targeted selection of culture medium components may lead to the enrichment of microorganisms exhibiting the desired abilities and provide new insight into their ecophysiology. The complexity and multistage nature of the biological $\mathrm{CH}_{4}$ formation process suggest that investigations are only valid when the community structure is studied using high throughput methods.

The specific aim of this study was to determine the link between the microbiome composition and methane production and to describe changes occurring in the methanogenic community structure and its metabolic capabilities as a function of the enrichment stage and medium composition. 


\section{Results}

The investigated sediments were characterized by slightly acidic reaction (5.46), redox potential (Eh) below $-265 \mathrm{mV}$, and organic carbon content equal to $48 \mathrm{~g} \mathrm{~kg} \mathrm{d.w.}{ }^{-1}$. The content of N-NH forms $_{4}$ was almost three times higher than the concentration of bioavailable phosphorus $\left(\mathrm{P}-\mathrm{PO}_{4}\right)(\mathrm{Table} 1)$.

Table 1. Characteristics of investigated sediments ( \pm SD).

\begin{tabular}{|c|c|c|c|c|c|c|c|c|c|}
\hline $\mathrm{N}-\mathrm{NO}_{2}$ & $\mathrm{~N}-\mathrm{NO}_{3}$ & $\mathrm{~N}-\mathrm{NH}_{4}$ & ${\mathrm{P}-\mathrm{PO}_{4}}_{4}$ & $\mathrm{TC}$ & IC & TOC & Moisture & \multirow{2}{*}{$\mathrm{pH}$} & \multirow{2}{*}{$\begin{array}{c}\text { Eh } \\
\mathrm{mV} \\
\end{array}$} \\
\hline \multicolumn{4}{|c|}{ mg kg d.w. ${ }^{-1}$} & & kg d.w. & & $\%$ & & \\
\hline $0.11 \pm 0.01$ & $0.30 \pm 0.04$ & $28.21 \pm 4.88$ & $10.05 \pm 0.25$ & $48.0 \pm 0.8$ & 0.00 & $48.0 \pm 0.8$ & $58.71 \pm 2.28$ & $5.46 \pm 0.02$ & $-265.63 \pm 2.89$ \\
\hline
\end{tabular}

\subsection{Methane Production}

$\mathrm{CH}_{4}$ production in the sediment samples (tested in laboratory conditions at temperatures $10-40^{\circ} \mathrm{C}$ ) revealed a maximum of over $1.67 \mathrm{mg} \mathrm{CH}_{4} \mathrm{~L}^{-1} \mathrm{~d}^{-1}$, at $30{ }^{\circ} \mathrm{C}$. The enrichment cultures were prepared in the same temperature range and in mineral media supplemented with different carbon sources. In the medium $\mathrm{H}(+)$, the highest methane production rate $\left(\mathrm{MP}\right.$, above $2.99 \mathrm{mg} \mathrm{CH}_{4} \mathrm{~L}^{-1} \mathrm{~d}^{-1}$, at 20 and $30^{\circ} \mathrm{C}$ ) was determined during stage S1. In the subsequent stages S2 $\left(20,30^{\circ} \mathrm{C}\right)$ and S3 $\left(30^{\circ} \mathrm{C}\right)$, the activities decreased and were significantly lower, ca. $1.28\left(20,30{ }^{\circ} \mathrm{C}\right)$ and $1.12 \mathrm{mg} \mathrm{CH}_{4} \mathrm{~L}^{-1} \mathrm{~d}^{-1}$ $\left(30^{\circ} \mathrm{C}\right)$, respectively. The supplementation of the medium with sodium acetate $(\mathrm{H}(+)$ acet $)$ resulted in MP of approximately $5.54 \mathrm{mg} \mathrm{CH}_{4} \mathrm{~L}^{-1} \mathrm{~d}^{-1}$ in the S1 stage, whereas one third of that value was noted in S2 and S3. Substantially higher MP was revealed when the headspace gas in the serum vials was replaced by methanogenic substrates: $\mathrm{CO}_{2}$ and $\mathrm{H}_{2}(20: 80 \mathrm{v} / \mathrm{v})$. In this case, the optimal temperature was $30^{\circ} \mathrm{C}$. MP increased with each subsequent stage of incubation. It was the highest in S3 (exceeding $12.8 \mathrm{mg} \mathrm{CH}_{4} \mathrm{~L}^{-1} \mathrm{~d}^{-1}$ ). This value was also the highest among all the experimental treatments. When the medium was free of tryptone and yeast extract but supplemented with sodium acetate $(\mathrm{H}(-)$ acet), methane production above $3.8 \mathrm{mg} \mathrm{CH}_{4} \mathrm{~L}^{-1} \mathrm{~d}^{-1}$ was observed at 20-40 ${ }^{\circ} \mathrm{C}$ in S1. In S2, MP decreased significantly, maximally by $83 \%$ with optimal thermal conditions noted at $20^{\circ} \mathrm{C}$. At this temperature, the $\mathrm{CH}_{4}$ production rate reached $1.74 \mathrm{mg} \mathrm{CH}_{4} \mathrm{~L}^{-1} \mathrm{~d}^{-1}$, and the reduction of MP was the lowest but still substantial, i.e., 57\%, compared to S1. In S3, the value of MP was similar to that in S2. In the $\mathrm{H}(-)$ medium and the $\mathrm{CO}_{2}$ and $\mathrm{H}_{2}$ atmosphere (20:80 v/v), MP was the highest at 30 and $40{ }^{\circ} \mathrm{C}$ in $\mathrm{S} 1$. However, in the next stage (S2), $30{ }^{\circ} \mathrm{C}$ appeared to be more suitable for methanogenesis, with MP reaching as much as $10.23 \mathrm{mg} \mathrm{CH}_{4} \mathrm{~L}^{-1} \mathrm{~d}^{-1}$. In S3, MP was still high, i.e., $8.85 \mathrm{mg} \mathrm{CH}_{4} \mathrm{~L}^{-1} \mathrm{~d}^{-1}$ (Figure 1).

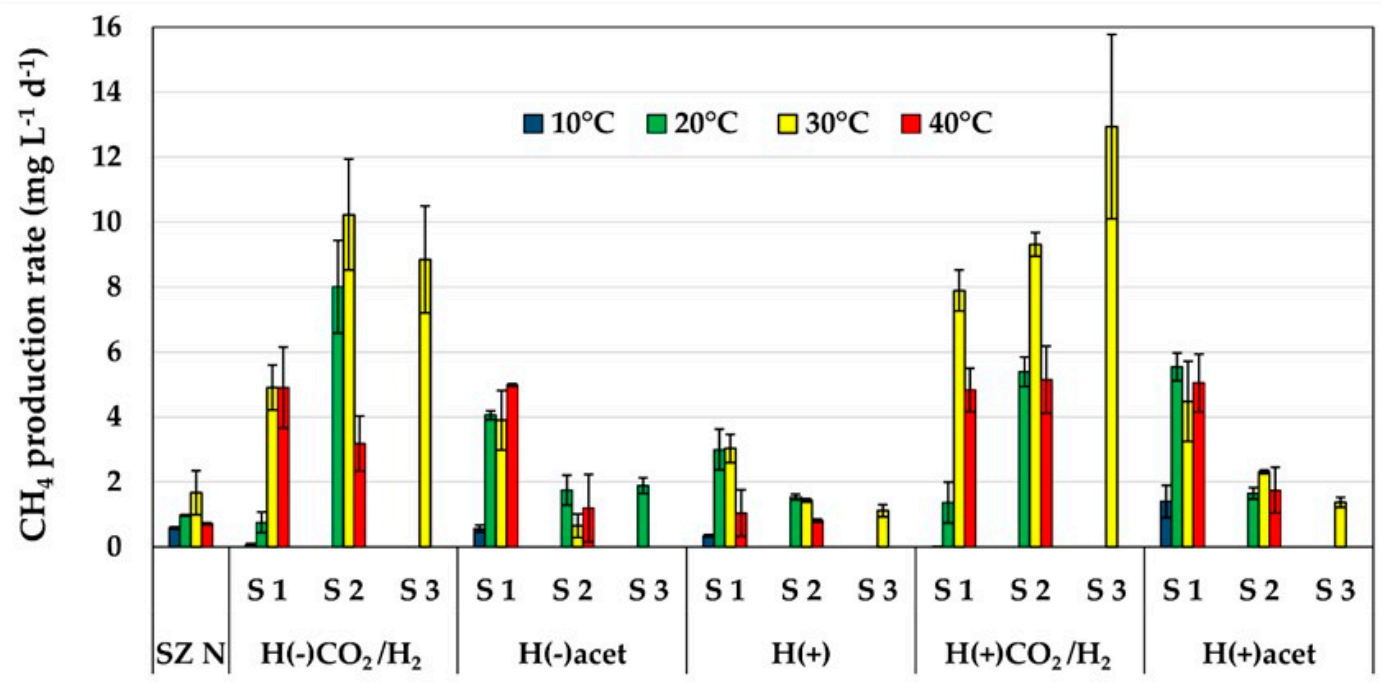

Figure 1. Methane production rate in particular media and stages of enrichment. Mean values with standard deviation (SD) are presented. 
The changes in the duration of the lag phase of MP indicate that the microbial consortia that developed in all of the treatments are able to metabolize the substrates added and create suitable conditions for methanogenesis. The lag phase was the longest in the initial phase of the experiment (S1) and shortened after the subsequent transfers (Table 2). The rise in temperature also caused a reduction in the lag phase. Starting from S2, in almost all experimental treatments, at 30 and $40{ }^{\circ} \mathrm{C}$, methane production began within one day of inoculation. The only exception was the community grown with acetate as the sole carbon source ( $\mathrm{H}(-)$ acet). This community was not only characterized by the longest lag time but also saw optimal growth at $20^{\circ} \mathrm{C}$.

Table 2. Lag phase duration in particular media and stages of enrichment.

\begin{tabular}{|c|c|c|c|c|c|c|}
\hline \multirow{2}{*}{ Stages of Bacterial Cultivation } & \multirow{2}{*}{ Temperature $\left({ }^{\circ} \mathrm{C}\right)$} & \multicolumn{5}{|c|}{ Lag Phase (d) } \\
\hline & & $\mathrm{H}(-) \mathrm{CO}_{2} / \mathrm{H}_{2}$ & H(-)acet & $\mathbf{H}(+)$ & $\mathrm{H}(+) \mathrm{CO}_{2} / \mathrm{H}_{2}$ & $\mathrm{H}(+)$ acet \\
\hline \multirow{4}{*}{ S1 } & 10 & 14 & 31 & 14 & 14 & 31 \\
\hline & 20 & 10 & 21 & 10 & 10 & 10 \\
\hline & 30 & 1 & 10 & 1 & 1 & 1 \\
\hline & 40 & 1 & 7 & 1 & 1 & 1 \\
\hline \multirow{3}{*}{$\mathrm{S} 2$} & 20 & 6 & 6 & 6 & 1 & 6 \\
\hline & 30 & 1 & 7 & 1 & 1 & 1 \\
\hline & 40 & 1 & 6 & 1 & 1 & 1 \\
\hline \multirow{2}{*}{ S3 } & 20 & - & 4 & - & - & - \\
\hline & 30 & 1 & - & 1 & 1 & 1 \\
\hline
\end{tabular}

\subsection{Physicochemical Conditions}

The $\mathrm{pH}$ value at the beginning of the incubation in $\mathrm{S} 1$ was generally slightly higher than at the end (Table 3). In the subsequent transitions, changes in the reaction depended on the treatment applied. Generally, $\mathrm{H}_{2}$ and $\mathrm{CO}_{2}$ resulted in slight acidification of the medium, while addition of organic carbon substrates promoted alkalization (Table 3). Based on the oxidation-reduction potential, it was found that the microbial communities were able to reduce the growth medium, with efficiency increasing from $\mathrm{S} 1$ to S3.

Table 3. Changes in physicochemical parameters between the start and the end of the particular stages of incubation $( \pm \mathrm{SD})$.

\begin{tabular}{|c|c|c|c|c|c|c|}
\hline \multirow{3}{*}{\multicolumn{2}{|c|}{$\begin{array}{c}\text { Stages of Bacterial } \\
\text { Cultivation/Parameters }\end{array}$}} & \multicolumn{5}{|c|}{ Medium Variants } \\
\hline & & $\mathrm{H}(-) \mathrm{CO}_{2} / \mathrm{H}_{2}$ & H(-)acet & $\mathrm{H}(+)$ & $\mathrm{H}(+) \mathrm{CO}_{2} / \mathrm{H}_{2}$ & $\mathrm{H}(+)$ acet \\
\hline & & \multicolumn{5}{|c|}{$\Delta$ (start to end) } \\
\hline \multirow[b]{2}{*}{$\mathrm{S} 1$} & $\mathrm{pH}$ & $-0.5 \pm 0.01$ & $-0.24 \pm 0.03$ & $-0.13 \pm 0.02$ & $-0.21 \pm 0.00$ & $-0.14 \pm 0.01$ \\
\hline & $\begin{array}{c}\text { Eh }(m V) \\
\text { OD }\end{array}$ & $\begin{array}{c}-383.20 \pm 0.32 \\
\text { na }\end{array}$ & $\begin{array}{c}-264.44 \pm 0.06 \\
\text { na }\end{array}$ & $\begin{array}{c}-337.27 \pm 0.40 \\
\text { na }\end{array}$ & $\begin{array}{c}-368.20 \pm 0.10 \\
\text { na }\end{array}$ & $\begin{array}{c}-303.87 \pm 0.25 \\
\text { na }\end{array}$ \\
\hline \multirow{3}{*}{$\mathrm{S} 2$} & $\mathrm{pH}$ & $-0.24 \pm 0.01$ & $1.07 \pm 0.00$ & $0.37 \pm 0.00$ & $-0.36 \pm 0.01$ & $0.79 \pm 0.02$ \\
\hline & Eh $(\mathrm{mV})$ & $-330.60 \pm 0.10$ & $-463.17 \pm 0.30$ & $-347.77 \pm 0.49$ & $-358.20 \pm 0.10$ & $-467.53 \pm 0.84$ \\
\hline & OD & $0.09 \pm 0.02$ & $0.08 \pm 0.02$ & $0.15 \pm 0.01$ & $0.09 \pm 0.02$ & $0.14 \pm 0.01$ \\
\hline \multirow{3}{*}{ S3 } & $\mathrm{pH}$ & $-1.18 \pm 0.02$ & $1.49 \pm 0.00$ & $0.16 \pm 0.04$ & $-1.56 \pm 0.04$ & $0.76 \pm 0.01$ \\
\hline & $\mathrm{Eh}(\mathrm{mV})$ & $-405.03 \pm 0.49$ & $-466.33 \pm 0.15$ & $-400.50 \pm 1.42$ & $-465.80 \pm 0.21$ & $-433.16 \pm 1.05$ \\
\hline & OD & $0.09 \pm 0.01$ & $0.07 \pm 0.02$ & $0.16 \pm 0.01$ & $0.16 \pm 0.02$ & $0.16 \pm 0.01$ \\
\hline
\end{tabular}

In the first stage of the experiment (S1), optical density $\left(\mathrm{OD}_{600}\right)$ was not measured due to the addition of a source material containing insoluble particles. In stages 2 (S2) and 3 (S3), the increase in turbidity was confirmed in all treatments, and significantly larger changes were revealed in the combinations with medium supplemented with yeast extract and tryptone $(\mathrm{H}+)$ and acetate addition than in those containing solely acetate or $\mathrm{CO}_{2} / \mathrm{H}_{2}$ (Table 3).

\subsection{Microbial Community Structure Across Sediment and Media Combinations}

As shown by the 16S rRNA gene analysis, Bacteria was the predominant domain in the sediment and enrichments in all stages of the experiment (Figure 2). The relative contribution of Archaea tended 
to increase with the successive stages of culture in media $\mathrm{H}(-)$ acet, $\mathrm{H}(+)$, and $\mathrm{H}(+)$ acet. Archaea species were the most prominent in $\mathrm{S} 3$ of the incubation in media $\mathrm{H}(+)$ and $\mathrm{H}(-)$ acet and accounted for 43 and $38 \%$, respectively, of the total microbial community. In media $\mathrm{H}(-) \mathrm{CO}_{2} / \mathrm{H}_{2}$ and $\mathrm{H}(+) \mathrm{CO}_{2} / \mathrm{H}_{2}$, the Archaea contribution decreased in the subsequent stages (Figure 2). The Archaea domain was dominated by methanogens, which accounted for almost $99 \%$ of the total Archaea.

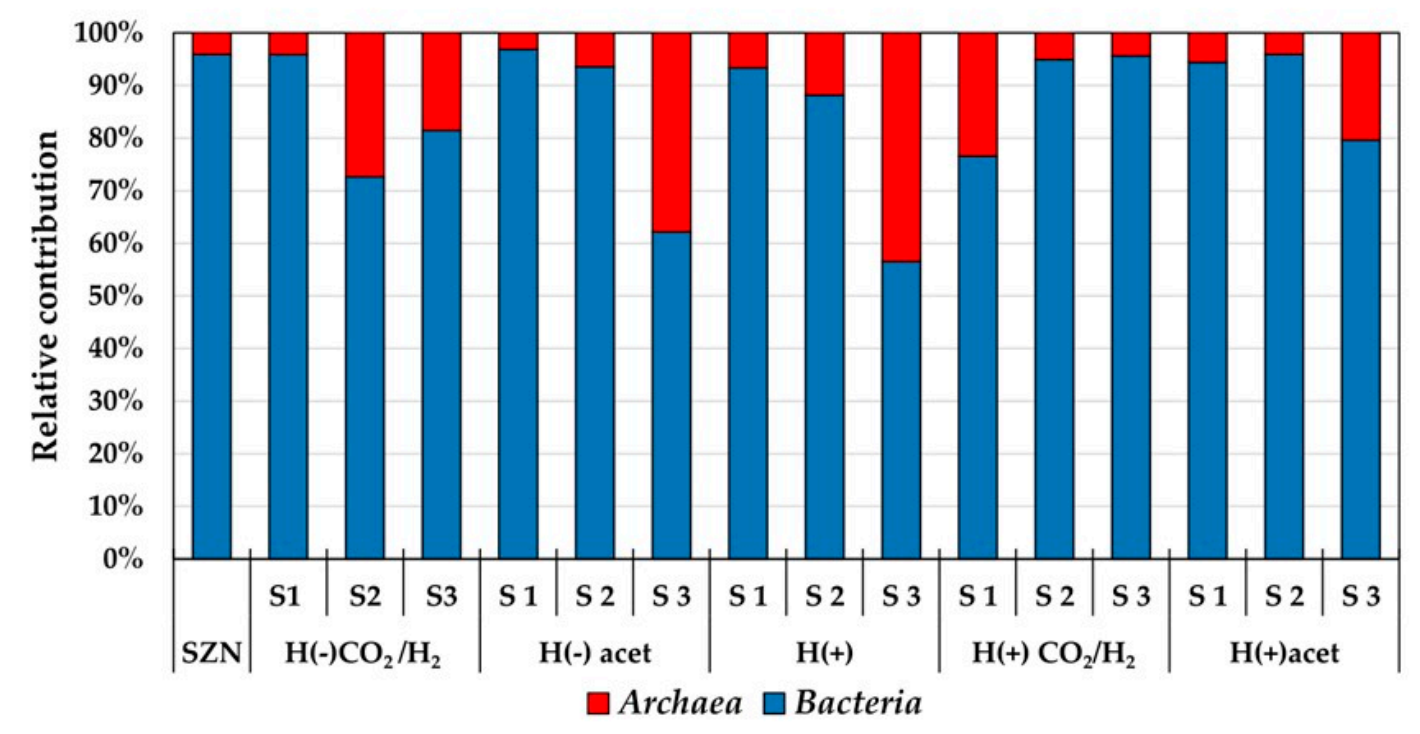

Figure 2. Archaea and Bacteria contribution in the particular stages of the experiment.

Representatives of the genus Methanothrix were the dominant methanogens in the bottom sediment; additionally, Methanocella, Methanobacterium, Methanoregula, Methanomassiliicoccus, Methanosarcina, and Methanolinea species and some methanogens that were not classified to any genus were identified (Figure 3). The culture in each medium resulted in differentiation of the methanogen composition. In the last step of the culture (S3), methanogenic communities grown on media $\mathrm{H}(-) \mathrm{CO}_{2} / \mathrm{H}_{2}, \mathrm{H}(+)$, and $\mathrm{H}(+) \mathrm{CO}_{2} / \mathrm{H}_{2}$ were dominated by Methanobacterium, which accounted for $100 \%, 57 \%$, and $85 \%$ of the identified methanogens, respectively. In media $\mathrm{H}(-)$ acet and $\mathrm{H}(+)$ acet, the main methanogen represented Methanosarcina ( $97 \%$ and $41 \%$ of all the methanogens, respectively). The second important genus identified in consortia growing in $\mathrm{H}(+)$ acet was Methanospirillum (35\%). The consortium from the medium combination $\mathrm{H}(+)$ additionally contained species from Methanothrix $(13 \%)$, while Methanomassiliicoccus identified in $\mathrm{H}(+)$ acet and $\mathrm{H}(+) \mathrm{CO}_{2} / \mathrm{H}_{2}$ accounted for $12 \%$ and $2 \%$ of the cultured methanogens, respectively.

The presence of non-methanogenic Archaea (Crenarchaeota (1.55\%) Woesearchaeota $(0.55 \%)$, Pacearchaeota $(0.26 \%)$ Diapherotrites $(0.015 \%)$, and Thaumarchaeota $(0.015 \%))$ was confirmed only in the native bottom sediment.

The structure of the microbial communities was clearly differentiated by available carbon sources. At the class level (Figure 4), Deltaproteobacteria (above 12\%) dominated in the sediment (SZN) followed by Actinobacteria (6.2\%), Betaproteobacteria (5.3\%), Bacteroidia (5.3\%), and Acidobacteria (5.3\%), which had smaller but significant contribution in the consortium. In the first stage (S1), Deltaproteobacteria dominated in $\mathrm{H}(+)$ acet, $\mathrm{H}(+) \mathrm{CO}_{2} / \mathrm{H}_{2}$, and $\mathrm{H}(+)$, Candidatus Cloacamonas in $\mathrm{H}(-) \mathrm{CO}_{2} / \mathrm{H}_{2}$, and Bacteroidia in $\mathrm{H}(-)$ acet. The proportion of the identified microorganisms changed during the next stages of the culture. In medium $\mathrm{H}(-) \mathrm{CO}_{2} / \mathrm{H}_{2}$ in the subsequent stages, an increasing proportion of Betaproteobacteria was noted (from $1.25 \%$ at the beginning to over $71 \%$ in the last stage of the culture). Increased contribution was also found in the case of Methanobacteria (from $0.4 \%$ to $26 \%$ and $18 \%$ in stages 2 and 3, respectively). The contribution of Betaproteobacteria increased with successive stages of the experiment when acetate was used ( $\mathrm{H}(-)$ acet, from 1.6 to $25.6 \%)$ as a sole carbon source, as in the case of Methanomicrobia, (from 2.1\% to 37.7\%). An increase in the contribution of Methanomicrobia was 
also noted in the subsequent stages of $\mathrm{H}(+)$ media enrichment (from $3.8 \%$ to $18.2 \%$ ). In the medium supplemented with multiple carbon sources $\mathrm{H}(+) \mathrm{CO}_{2} / \mathrm{H}_{2}$ (tryptone, yeast extract, and $\mathrm{CO}_{2}$ ), there was a significant increase in the contribution of Caldisericum (to over 30\%) between the first and last stages. Media based on tryptone, yeast extract, and acetate $(\mathrm{H}(+)$ acet $)$ caused an increase in the contribution of Clostridia as well as Methanomicrobia in the microbial community structure (Figure 4).

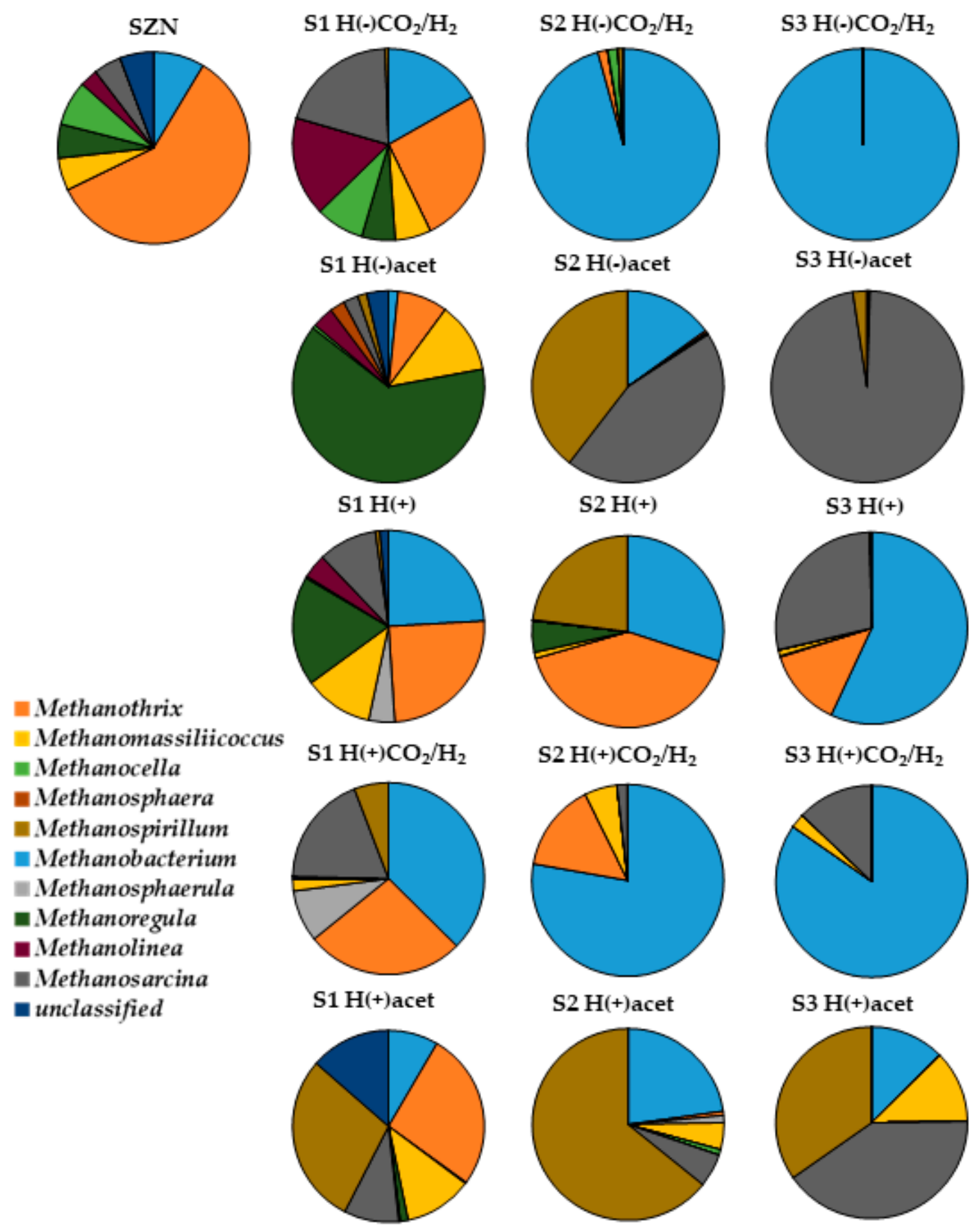

Figure 3. Changes in the methanogen community during incubation in different media. 
$\begin{array}{lllllllllll}0 \% & 10 \% & 20 \% & 30 \% & 40 \% & 50 \% & 60 \% & 70 \% & 80 \% & 90 \% & 100 \%\end{array}$

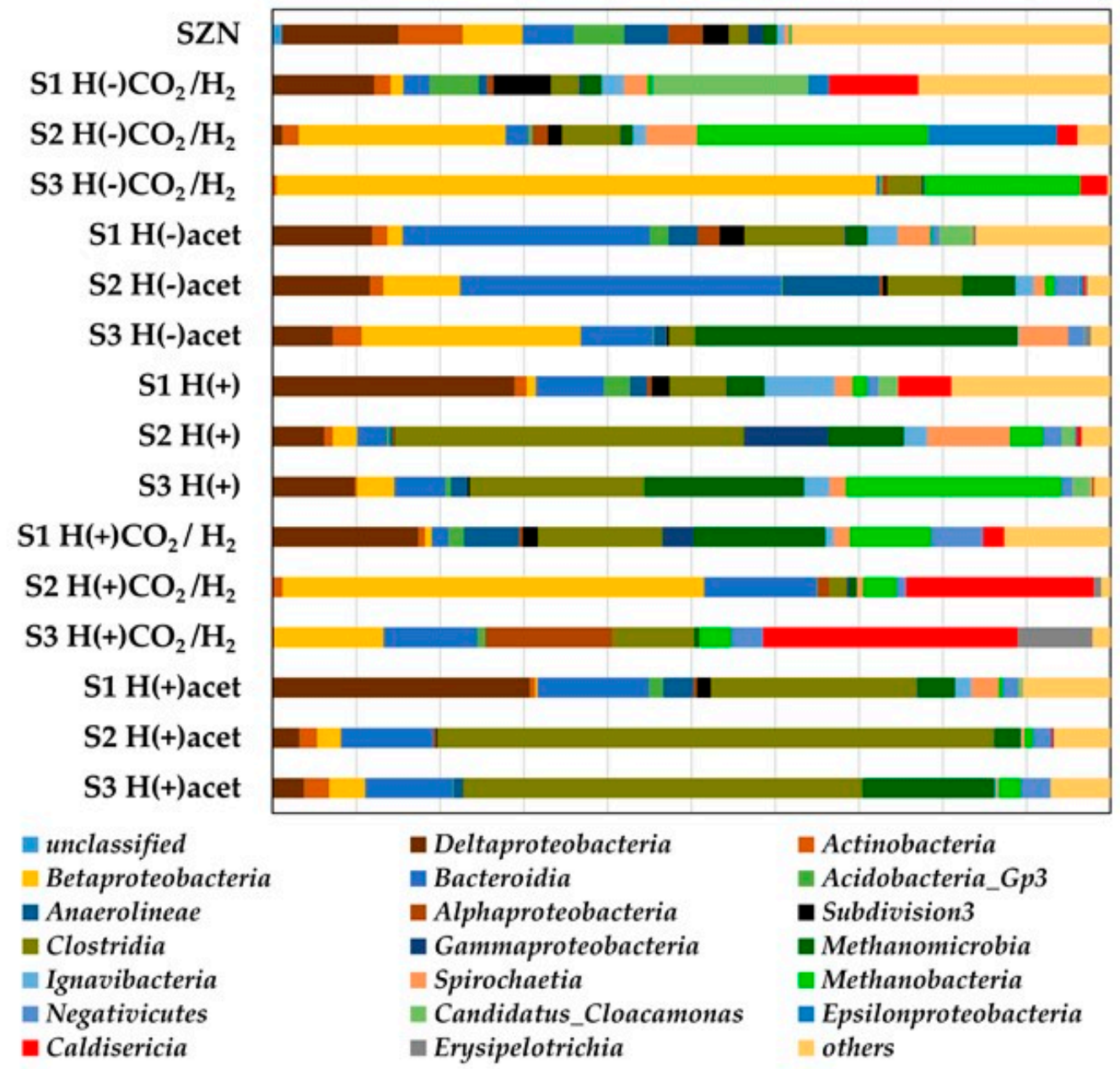

Figure 4. Diversity in the microbial communities at the class level (microbial classes represented by $>2 \%$ of total sequences, classes making up less than $2 \%$ were classified as others) in response to the different media composition and in the particular stage of enrichment identified by $16 \mathrm{~S}$ rRNA gene sequences.

\subsection{Microbial Biodiversity}

The microbial taxonomic diversity in the SZN sediment was high, which was reflected in the values of the biodiversity indices (Table 4). Analysis of the enrichment cultures revealed that the composition of the medium had a great impact on biodiversity. All indices used to describe the community composition as a function of the substrates added and the transition stage have shown that the $\mathrm{H}(-) \mathrm{CO}_{2} / \mathrm{H}_{2}$ and $\mathrm{H}(-)$ acet treatments in the first cultivation stage were characterized by the greatest biodiversity and harbored nearly half of the OTUs found in SZN. A great majority of OTUs found in the initial stages of the $\mathrm{H}(-) \mathrm{CO}_{2} / \mathrm{H}_{2}$ and $\mathrm{H}(-)$ acet treatments was lost during the subsequent transitions. The decrease was especially visible in the community that developed in $\mathrm{H}(-) \mathrm{CO}_{2} / \mathrm{H}_{2}$, where only 96 OTUs were detected in the final stage of the experiment. Surprisingly, similarly low final biodiversity (97 OTUs) was found in $\mathrm{S} 3$ of the $\mathrm{H}(+) \mathrm{CO}_{2} / \mathrm{H}_{2}$ variant. These two treatments also revealed the highest methanogenic activity which increased with subsequent transitions. The selection is confirmed by the values of the inverse Simpson index, which is strongly affected by the evenness of abundant species. Communities that developed in $\mathrm{H}(+) \mathrm{CO}_{2} / \mathrm{H}_{2}$ and $\mathrm{H}(-) \mathrm{CO}_{2} / \mathrm{H}_{2}$ in $\mathrm{S} 3$ were characterized by very low values of this index (7.6 and 2.1, respectively), which confirms that they were dominated by only a few microbial taxa (Table 4). The microbial consortia found in the other treatments were much more 
resistant to biodiversity loss. Interestingly, nearly 240 OTUs were still present in the communities grown on $\mathrm{H}(+)$ and $\mathrm{H}(+)$ acet in the final stage of cultivation (S3).

Table 4. Biodiversity indices of the experimental treatments.

\begin{tabular}{|c|c|c|c|c|c|c|c|c|}
\hline Treatment & Stage & Observed & Chao1 & ACE & Shannon & Simpson & InvSimpson & Fisher \\
\hline $\mathrm{SZN}$ & - & 2536 & 2585.96 & 2565.61 & 7.06 & 1.00 & 422.83 & 559.06 \\
\hline \multirow{3}{*}{$\mathrm{H}(-) \mathrm{CO}_{2} / \mathrm{H}_{2}$} & S1 & 1227 & 1232.69 & 1229.26 & 5.45 & 0.98 & 48.19 & 207.52 \\
\hline & $\mathrm{S} 2$ & 230 & 230.00 & 230.00 & 3.25 & 0.91 & 11.27 & 28.11 \\
\hline & S3 & 96 & 96.00 & 96.00 & 1.40 & 0.53 & 2.11 & 10.55 \\
\hline \multirow{3}{*}{$\mathrm{H}(-)$ acet } & S1 & 1206 & 1206.56 & 1206.80 & 5.41 & 0.98 & 64.49 & 202.84 \\
\hline & S2 & 317 & 317.00 & 317.14 & 3.64 & 0.94 & 15.39 & 41.54 \\
\hline & S3 & 184 & 184.00 & 184.20 & 2.59 & 0.80 & 5.00 & 22.77 \\
\hline \multirow{3}{*}{$\mathrm{H}(+)$} & S1 & 996 & 996.30 & 996.43 & 5.10 & 0.97 & 33.28 & 158.44 \\
\hline & S2 & 353 & 353.00 & 353.14 & 4.07 & 0.96 & 25.17 & 48.10 \\
\hline & S3 & 238 & 238.00 & 238.00 & 3.38 & 0.92 & 11.96 & 30.61 \\
\hline \multirow{3}{*}{$\mathrm{H}(+) \mathrm{CO}_{2} / \mathrm{H}_{2}$} & S1 & 574 & 574.00 & 574.14 & 4.93 & 0.98 & 66.40 & 85.08 \\
\hline & $\mathrm{S} 2$ & 121 & 121.00 & 121.00 & 1.89 & 0.69 & 3.27 & 13.60 \\
\hline & S3 & 97 & 97.00 & 97.00 & 2.67 & 0.87 & 7.63 & 10.80 \\
\hline \multirow{3}{*}{$\mathrm{H}(+)$ acet } & S1 & 530 & 530.00 & 530.00 & 4.72 & 0.97 & 39.57 & 69.79 \\
\hline & S2 & 335 & 335.00 & 335.14 & 3.54 & 0.91 & 10.83 & 44.04 \\
\hline & S3 & 241 & 241.00 & 241.28 & 3.83 & 0.95 & 20.53 & 31.56 \\
\hline
\end{tabular}

The beta-diversity analysis confirmed the significance of differences between the communities. The reconstructed tree describing divergence has shown clearly that the substrates added to the culturing medium were the main factors affecting the composition of the $\mathrm{SZN}$-derived communities (Figure 5). $\mathrm{CO}_{2} / \mathrm{H}_{2}$ seems to be the primary differentiating factor. Communities that developed in $\mathrm{H}(+) \mathrm{CO}_{2} / \mathrm{H}_{2}$ and $\mathrm{H}(-) \mathrm{CO}_{2} / \mathrm{H}_{2}$ formed a separate branch and exhibited only a $15 \%$ similarity to those grown on solely organic compounds. The differences between the communities grown on organic substrates were smaller.

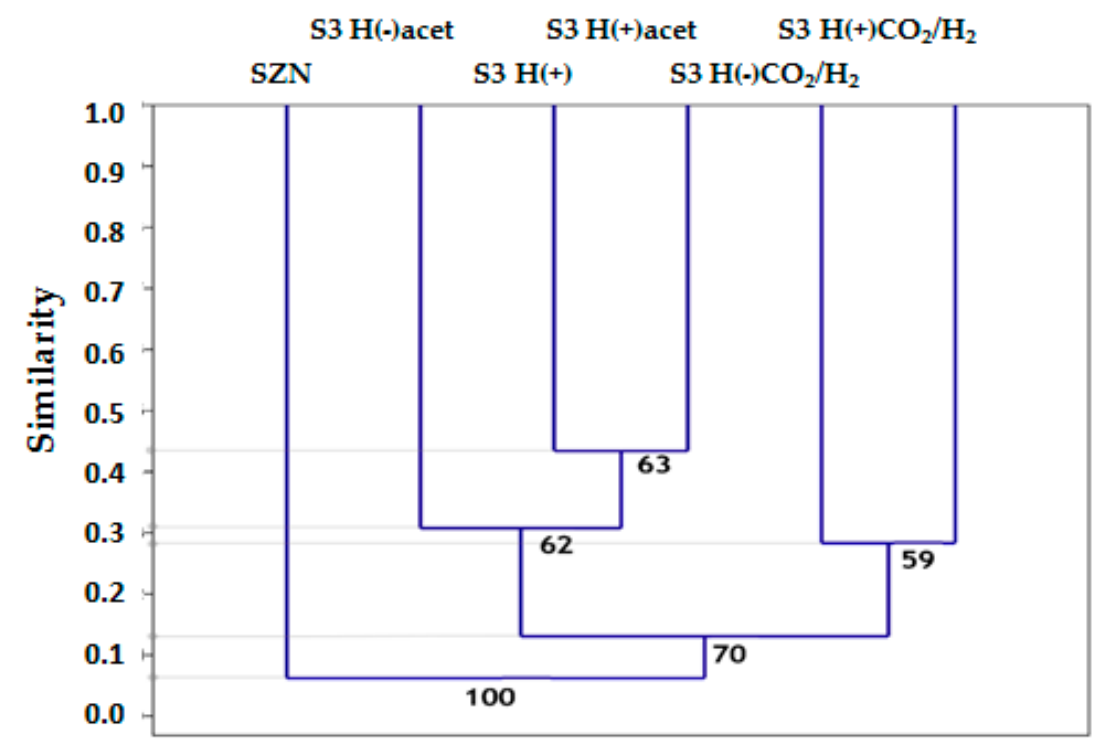

Figure 5. Beta-diversity of the bacterial communities in the experimental treatments. The similarity presented on the scale was calculated based on the Bray-Curtis distances, and the tree was generated by an UPGMA algorithm. The bootstrap number was set to 999. 


\section{Discussion}

\subsection{Lake Sediment}

Methane production in the sediment (SZN) ranged from 0.58 to over $1.67 \mathrm{mg} \mathrm{CH}_{4} \mathrm{~L}^{-1} \mathrm{~d}^{-1}$ depending on the incubation temperature and with a maximum at $30^{\circ} \mathrm{C}$. These values were in the range of the methane production determined for river and pond sediments investigated by Yang [26] in northern Taiwan (0.24-18.0 $\left.\mathrm{mg} \mathrm{CH}_{4} \mathrm{~L}^{-1} \mathrm{~d}^{-1}\right)$ and for Lake Kinneret in Israel (0.38-7.68 $\left.\mathrm{mg} \mathrm{CH}_{4} \mathrm{~L}^{-1} \mathrm{~d}^{-1}\right)$ investigated by Schwarz and co-workers [27]. Methane formation was also higher than that found in sludges from acidic bog lakes Grosse Fuchskuhle (Germany) (0.032-0.368 $\mathrm{mg} \mathrm{CH}_{4} \mathrm{~L}^{-1} \mathrm{~d}^{-1}$ ) [28].

Methanogens, with the dominant Methanosarcinales (Methanothrix and Methanosarcina) able to utilize a number of different substrates, e.g., $\mathrm{CO}_{2}, \mathrm{H}_{2}$, and acetate (Figure 3), were responsible for the methane production in the Szczecin reservoir sediment. The contribution of representatives of Methanobacteriales, Methanomicrobiales, Methanocellales and Methanomassiliicoccales was much lower. This situation is different from that in eutrophic and mesotrophic lakes (Dianchi and Erhai, China) where the dominance of Methanomicrobiales and Methanobacteriales was confirmed, and, despite the slightly acidic reaction of the Szczecin reservoir sediment, was similar to the alkaline soda lake (Mono Lake, CA, USA) dominated by Methanosarcinales and Methanomicrobiales [29,30]. A similar methanogenic community structure was also found in several Amazonian lake sediments with variable pH (5.7 to 8.1) [31]. Deltaproteobacteria, Actinobacteria, Betaproteobacteria, Bacteroidia, and Acidobacteria (more than 5\% contribution) dominated among the accompanying bacteria in the Szczecin reservoir sediment. The microbial community was slightly similar to that detected in eutrophic Chinese lakes, where Deltaproteobacteria, Betaproteobacteria, Gammaproteobacteria, Alphaproteobacteria, Anaerolineae, and Nitrospira were the dominant classes [32].

\subsection{Enrichment Cultures}

In each treatment, MP was observed after the lag phase. Its occurrence at the beginning of the culture-based experiment results from adaptation to changed conditions [33]. In our experiment, where the $\mathrm{CH}_{4}$ dynamics was of central importance, the lag phase duration reflects the time necessary for reduction of the culture medium to sufficiently low redox conditions. It could be expected that biodiversity loss would impair self-reduction potential of the microbial community. Our experiment shows that sediment derived from an instable subsidence reservoir (Szczecin) harbors a community that is able to maintain (or even increase) the self-reduction potential in spite of the substantial reduction of biodiversity. Furthermore, although the lag phase was the shortest in the cultures grown with $\mathrm{H}_{2}$ (which is a reducing agent itself) other substrates also supported the fast creation of conditions suitable for methanogenesis, which is important when considering further research of the biotechnological potential of the community.

\subsection{Microbial Biodiversity}

The biodiversity in the SZN sediment (Table 4) was similar to that in other lake sediments worldwide (analyzed using the analogous sequencing depth) [34,35] and higher than values typically calculated for soil $[36,37]$ or freshwater [38,39]. This confirms that the transitional environments of the sediments harbor much higher microbial diversity that the adjacent environments.

Microbial diversity was largely lost in the enrichments. The highest decline was noted between SZN and S1 of the cultures for all calculated indexes (Table 4). It should be noted that the trophic structure of the microbial community in the S1 cultures was still influenced by the availability of organic matter originating from the basal sediment (dilution $2 \times 10^{-2}$ ). The second stage S2 was transitional, while at the third stage of cultivation when the availability of the basal material was $8 \times 10^{-6}$, the community was in fact dependent only on substrates delivered by the experimental medium. The decrease in biodiversity between the second and third stage of culturing was low, which suggests that the S3 community structures were determined mainly by the experimental conditions. 
Subsequent transitions resulted in a decrease in unidentified sequences, which probably points to the disappearance of species that are not able to grow when deprived of the natural sediment and are unculturable to date. Furthermore, it was found that a majority of the genera that were lost during the successive stages of the experiment were aerobic (Gaiella, Gemmatimonas, Nitrospira, Conexibacter, Methylobacter, Thermoleophilum, Kofleria) or microaerobic (Sideroxydans, Magnetococcus, Anaeromyxobacter, and Sterolibacterium - threshold of $1 \%$ of the reads in SZN. The presence of aerobic microorganisms confirms the transitional character of the SZN sediment and the dualistic character of the microbial community (aerobic/anaerobic). The loss of aerobes was a consequence of the application of the culturing conditions.

The structure of the microbial communities was shaped by the available carbon sources (Figure 4). Adaptation to the culturing conditions (available carbon sources) was also clearly visible for the methanogens. Methanothrix, which is the most frequent Archaea in the SZN sediment, disappeared gradually in a majority of the treatments. In the third stage of the experiment, it was outcompeted by other methanogenic genera (Figure 3). The differentiation reflected the metabolic capabilities of Archaea. The availability of the thermodynamically beneficial energy source $\left(\mathrm{H}_{2}\right)$ led to increased contribution of hydrogenotrophic Methanobacterium (in $\mathrm{H}(+), \mathrm{H}(-) \mathrm{CO}_{2} / \mathrm{H}_{2}$, and $\mathrm{H}(+) \mathrm{CO}_{2} / \mathrm{H}_{2}$ ) while the addition of acetate to the culture medium $(\mathrm{H}(+)$ acet and $\mathrm{H}(-)$ acet promoted Methanosarcina. In this case, our experiment confirms the previously described fact that although both are acetotrophic, Methanothrix and Methanosarcina differ in the kinetics of enzymes involved in acetate assimilation. Hence, low acetate concentrations favour Methanothrix, which is outcompeted by Methanosarcina at high acetate levels [40].

Methanothrix almost completely disappeared at $\mathrm{S} 3$ of the experiment. Only in the $\mathrm{H}(+)$ culture, at S3, did it still account for $13 \%$ of the methanogens (Figure 3). If the outcompetition of Methanothrix by Methanosarcina can indeed be explained by competition for the substrate, the disappearance of Methanothrix in $\mathrm{H}(+)$ acet and $\mathrm{H}(-)$ acet requires additional explanation. The composition of the basal medium (vitamins and trace element content) was the same in all cultures. Therefore, it seems that the primary cause of the changes in methanogen contribution would be the associated bacterial community (differentiated by the available carbon source).

Methanothrix may lack some key compounds, e.g., auxotrophic vitamins or amino acids. Recently, Hubalek et al. [41] presented a comprehensive study showing that the proportion of genes encoding auxotrophy for vitamins and amino acids in the metagenome-assembled genomes of anaerobic, hydrocarbon-degrading communities is surprisingly high compared to those linked with energy conservation. This led them to the conclusion that metabolic interactions between obligate mutualistic microbial partners should be of central importance because beyond the canonical $\mathrm{H}_{2}$-producing and syntrophic bacteria - methanogen partnership, a complex (although not fully defined) interactions play an important role in determination of the metabolism of the entire community.

Our study shows that the cooperation between acetotrophic methanogens (Methanothrix) and acetogenic bacteria may be one of those relationships. It has already been proven that Methanosarcina owe its physiological flexibility to Clostridia - the most probable source of a unique (as for Archaea) enzymatic system employing acetate kinase (AckA) and phosphoacetyl transferase (Pta) [42]. Enzymes involved in methane production from acetate may not be the only ones "imported" via gene transfer. It cannot be excluded that other genes, not yet identified but enhancing survival in environmental conditions, were also incorporated by Methanosarcina. Methanothrix seems to lack such benefits. In this work, we found a relationship between the contribution of Methanothrix and acetogenic bacteria (the latter presented as KEGG-revealed expected abundances of genes responsible for the synthesis of enzymes involved in the acetate-generating Wood-Ljungdahl pathway - carbon monoxide dehydrogenase [EC 1.2.7.4]/acetyl-CoA synthase [EC 2.3.1.169]). We hypothesize that Methanothrix gains more benefits from cooperation with acetogenic bacteria than from substrate delivery and interspecies electron transfer. Examples of such a relationship have already been demonstrated in co-cultures (alanine transfer between Methanococcus maripaludis and Desulfovibrio vulgaris [43]). 
A support for the deduced relationships seems to be the disappearance of Methanothrix in treatments containing acetate, where the growth of acetogenic bacteria was inhibited by excess product concentration (via a mechanism described previously by Wang and Wang [44] (Figure 6). Full confirmation of the necessity of Methanothrix - acetogen cooperation requires comprehensive studies. The use of model co-cultures subjected to transcriptional, proteomic and metabolic analyses or shotgun metagenome/metatranscriptome analyses of environmental samples would explain the exact nature of the deduced cooperation between Methanothrix and acetogenic bacteria.

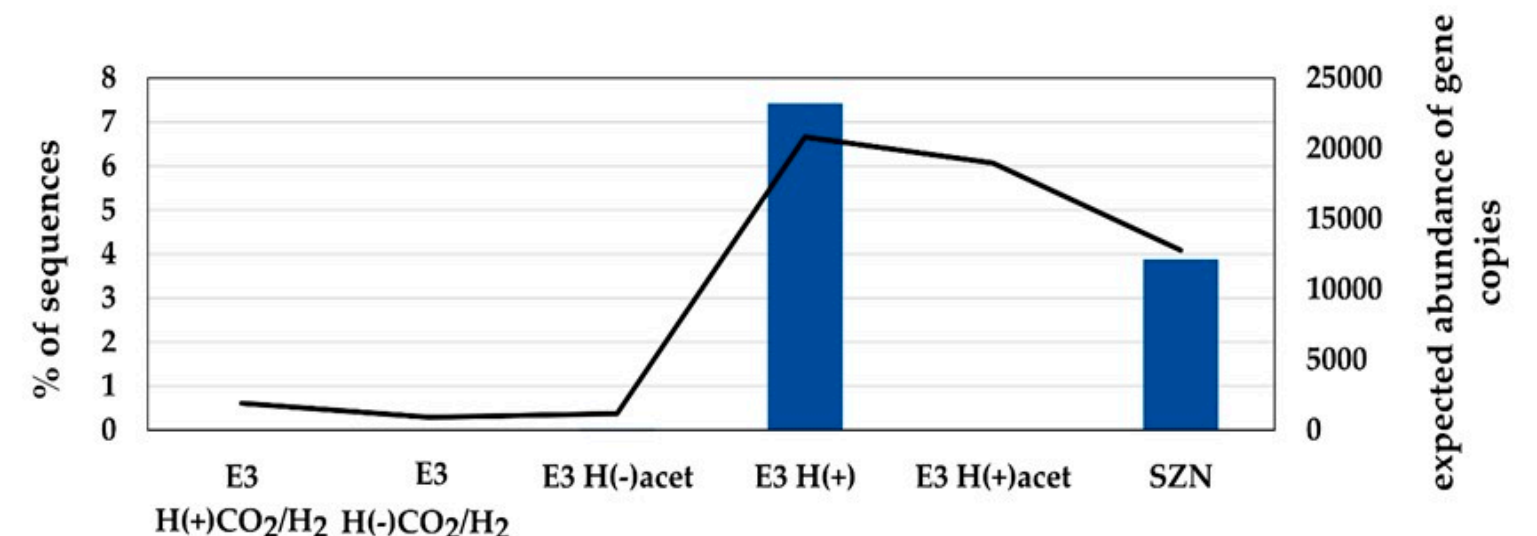

$\mathrm{H}(+) \mathrm{CO}_{2} / \mathrm{H}_{2} \mathrm{H}(-) \mathrm{CO}_{2} / \mathrm{H}_{2}$

Methanothrix - carbon monoxide dehydrogenase / acetyl-CoA synthase

Figure 6. Relative contribution of Methanothrix and acetogenic bacteria (the latter presented as KEGG-revealed expected abundances of genes responsible for the synthesis of enzymes involved in the acetate-generating Wood-Ljungdahl pathway - carbon monoxide dehydrogenase [EC 1.2.7.4]/acetyl-CoA synthase [EC 2.3.1.169].

Interestingly, the proportion of methanogens was not in line with the methane production rate detected in vivo (Figure 1). The treatment that exhibited the highest methane production (growing with each transfer and characterized by the shortest lag phase) was also characterized by a very low proportion of the identified methanogens ( $4.3 \%$ of the reads). Instead, unexpectedly, high contribution of Caldiserica was found in $\mathrm{H}(+) \mathrm{CO}_{2} / \mathrm{H}_{2}$. These bacteria are one of the most intriguing elements of the SZN consortium. Caldiserica, formerly known as OP5, was first described based on environmental 16S rRNA fragments isolated from Obsidian Pool (Yellowstone) [45]. The first culturable species of the phylum, i.e., Caldisericum exile, was isolated by Mori and co-workers a decade later [46] from a hot spring in Japan. In the present experiment, Caldiserica was found in almost all of the treatments and was particularly abundant in $\mathrm{H}(+) \mathrm{CO}_{2} / \mathrm{H}_{2}$. The culturing conditions in which $\mathrm{CO}_{2} / \mathrm{H}_{2}$, yeast extract, and tryptone were used were highly suitable for these bacteria, whose participation in the community structure grew successfully with the consecutive culture stages reaching over $30 \%$ of the sequence reads in S3. In the other variants containing $\mathrm{H}_{2} / \mathrm{CO}_{2}$, yeast extract, and tryptone separately, they accounted for $0.17 \%$ and $3.2 \%$ of the sequences in the final stage of the experiment. Almost no Caldiserica representatives were detected in the treatments containing acetate (even in the presence of yeast extract $(\mathrm{H}(+)$ acet $))$.

C. exile, the only known culturable representative of the phylum to date, was described as anaerobic, thermophilic, and thiosulfate-reducing bacterium. Therefore, it could be expected that the presence of Caldiserica would hinder methane production by competition for hydrogen with methanogens. In this work, we found that the presence of huge numbers of Caldiserica did not reduce methanogenesis but seemed to even stimulate it. Similar observations have been reported by Ma and co-workers [47], who investigated degradation of hexadecane to methane as a function of sulphate concentration. In that research, the most effective culture (containing $0.5 \mathrm{mM}$ sulphate) contained a high proportion of Caldiserica. These authors did not emphasize the role of Caldiserica but their analysis of the whole 
community suggested that there is a possibility of cooperation between incomplete-oxidizing sulphate reducers and methanogens, as incomplete oxidation of organic intermediates may generate $\mathrm{H}_{2}$ through sulphate reduction. In fact, sulphur disproportionation may be carried out with protons being either a substrate or a product of the reaction, as described below (Equations (1), (2)) [48,49]:

$$
\begin{gathered}
\mathrm{S}_{2} \mathrm{O}_{3}{ }^{2-}+2 \mathrm{H}^{+}+2 \mathrm{e}^{-} \rightarrow \mathrm{HS}^{-}+\mathrm{HSO}_{3}{ }^{-} \\
\mathrm{S}^{2} \mathrm{O}_{3}{ }^{2-}+\mathrm{H}_{2} \mathrm{O} \rightarrow \mathrm{SO}_{4}{ }^{2-}+\mathrm{HS}^{-}+\mathrm{H}^{+}
\end{gathered}
$$

The ecology of Caldiserica is currently being discovered and described. The first reports on representatives of the phylum were associated with extreme thermophilic environments, e.g., the hot springs mentioned above [50] and hydrothermal vents [51]. Further studies provided growing evidence that representatives of the phylum can occupy other environmental niches as well. Interestingly, their high contribution (reaching as much as $60 \%$ of the total community) has been confirmed in permafrost [52,53], which denies their exclusively thermophilic character. Additionally, a negative effect of the increased temperature has been observed in this specific location [52]. Caldiserica was also identified in lake waters both in deep anoxic parts [54] and, surprisingly, the upper layers [55]. The results presented in this study pointing to the presence of these bacteria in the sediments of the shallow subsidence reservoir support the recent discoveries of Caldiserica capability to live in mesophilic conditions or even temperatures close to zero (such as those occurring in shallow lake sediments in winter) and to cope with oxidative stress. Bearing in mind the variety of environments occupied by Caldiserica (evidence of genomic diversity), it may be expected that the methodological progress in the field of environmental genomics will soon facilitate description of other species belonging to this phylum colonising various environments and eluding culturing attempts.

Other representatives of microbial "dark matter" that have recently come into the limelight and were found in the Szczecin reservoir sediments were those of Methanomassiliicoccus. This methanogenic methylotrophic Archaea was first described in human faeces [56]. Further, its relatives were found in the intestinal tracts of other organisms [57] or faeces-affected sludges (e.g., from wastewater treatment plants) $[58,59]$. Most research of these microorganisms focuses on their interaction with human health [60-62] or the unique methylotrophic but $\mathrm{H}_{2}$-dependent metabolism [63]. Methanogenic Thermoplasmata (including Methanomassilicoccales) use a reduced methanogenic pathway, in which methanol and other methylated compounds are reduced to methane in the presence of $\mathrm{H}_{2}$ [56]. This metabolic pathway has long been considered to have minor environmental importance, as it was reported to be used by only two methanogenic species. Recently, the visibility of Thermoplasmata-related sequences has been enhanced by the description of culturable species and M. luminensis genome sequence deposition in public databases [64]. The ecology of this newly described archaeal phylum is currently being recognized. Comparative phylogenetic studies performed by Paul et al. [65] have implied that Methanomassiliicoccales may be a part of the microbiome occurring in various environments. To date, these assumptions have been confirmed for extreme environments such as hot springs [66], formation waters connected with oil reservoirs [67], wetland soils [68], lake sediments [69], and deep subsurface (coal) [70]. The present study, indicating that the Szczecin reservoir sediment (SZN) is occupied by Methanomassiliicoccaceae, is in line with the aforementioned discoveries and is the second report, after Fan and Xing [69], on their presence in lake sediments. Surprisingly, the enrichment cultures in the presented experiment revealed that this group of methanogens is especially enriched in the presence of acetate. All currently published enrichment cultures and a sole M. luminyensis isolate were obtained on methanol or methylamines as a carbon source and $\mathrm{H}_{2}$ [68]. Hence, it could be expected that Methanomassiliicoccus would find the best growth conditions in medium $\mathrm{H}(+) \mathrm{CO}_{2} / \mathrm{H}_{2}$, where organic substrates and hydrogen were added. Surprisingly, only $0.17 \%$ of the sequences in this treatment were affiliated to this genus, vs. nearly $2.5 \%$ in $\mathrm{H}(+)$ acet, which means that it was 27 times more abundant in these conditions than in the original sediment. These results contrast with previous studies of Methanomassiliicoccus-containing enrichment cultures. In experiments presented by Lv et al. [67], 
addition of acetate to the culture medium resulted in replacement of Methanomassiliicococcacae by Methanosaeta and Methanosarcina (both known for acetotrophic metabolism). In the present study, Methanosarcina was also dominant in all acetate-amended cultures (which is not a surprise) but in $\mathrm{H}(+)$ acet Methanomassiliicoccus accounted for nearly $12 \%$ of all methanogens. The difference between these two experiments may result from the different origin of the inoculates. Lv and co-workers [67] investigated communities derived from oil production waters, while our study was developed based on a community retrieved from a shallow lake sediment; therefore, they may represent distinct species. The utilization of acetate by Methanomassiliicoccaceae in lake sediments may be a result of adaptation to in situ conditions. Shallow lake littoral zones are often overgrown by aquatic macrophytes. The roots of these plants are known to exude organic acids. Acetate is thus an abundant substrate in the sediment and, provided anaerobiosis is maintained, can be used by methanogens. Our hypothesis pointing to stimulation of Methanomassiliicoccaceae by acetate exudates seems to be confirmed also by Fan and Xing [69], who reported that representatives of the genus are more abundant in littoral- macrophyte overgrown sediments than in deeper parts of the lake (dominated by algae). Also, the sequence retrieved from the SZN metagenome exhibited high similarity with 16SrDNA fragments isolated from environmental littoral samples overgrown by reed (AB896665.1) and rice (KU522088.1; GU134476.1).

\section{Materials and Methods}

The research material was bottom sediment $(0-5 \mathrm{~cm})$ of an endorheic reservoir named Szczecin $\left(51^{\circ} 20^{\prime} 18^{\prime \prime} \mathrm{N} 22^{\circ} 59^{\prime} 45^{\prime \prime} \mathrm{E}\right.$, Lublin region, Poland). The reservoir developed in 1995 in the post-mining subsidence as result of underground operations carried out in the nearby "Bogdanka" coal mine (Lublin Coal Basin). Its area is about 100 ha and the maximum depth is approximately $2.5 \mathrm{~m}$ [71]. The reservoir basement is formed of sandy-clay soil, which is characteristic of the area [72]. The water in the reservoir has become eutrophic since nutrients are likely to get into the water from nearby fields [73]. Sediments were taken in triplicate in the summer of 2016 (Piston sampler, Eijkelkamp, Nederland). They were transferred into tightly closed sterile jars, transported to the laboratory, and kept at $5{ }^{\circ} \mathrm{C}$ for a few days until the experiment started and at $-20^{\circ} \mathrm{C}$ for the molecular analyses.

\subsection{Physical and Chemical Analysis}

The sediment moisture was determined gravimetrically by oven-drying to a constant weight at $105^{\circ} \mathrm{C}$, immediately after collecting the samples. Reaction $(\mathrm{pH})$ and redox potential (Eh) were determined using a multifunctional potential meter Sension+ MM150 and a multi-sensor for $\mathrm{pH}$ and Eh (HACH, USA). The carbon content in dry samples was determined by means of TOC- $\mathrm{V}_{\mathrm{CSH}}$ with an SSM-5000A module autoanalyzer (Shimadzu, Japan). The total organic carbon (TOC) amount was calculated from the difference between total carbon (TC) and inorganic carbon (IC) [74]. Bioavailable forms of nitrogen (nitrite, nitrate, ammonium) and phosphorus were measured in bottom sediment extracts (sediments with deionized water and with $0.5 \mathrm{M} \mathrm{NaHCO}_{3}$ for nitrogen and phosphorus forms respectively) using an AA3 autoanalyzer (Braun \& Luebbe, Germany) after filtering through filter paper (Munktell, grade 390, Germany) according to the method described by Banach [75].

\subsection{Incubation Experiments}

\subsubsection{Assessment of the Methane Production Rate in Sediment}

Each stage of methanogenic incubation was prepared aseptically in anoxic conditions with a nitrogen atmosphere (glove box chamber, Labconco, Kansas City, MO, USA). At the beginning, the natural capability of methane production in the sediments (SZN) was tested. Ten millilitres of bottom sediments were placed in 60-mL serum vials, closed with butyl rubber septa, and capped. Samples were incubated at temperatures of $10,20,30$, and $40^{\circ} \mathrm{C}$ for up to 90 days, always in triplicate. 


\subsubsection{Cultivation Conditions of the Enrichment Cultures}

The media were prepared according to Horn [76] with slight modifications. Sterile (autoclaved) medium containing (milligrams per litre) $\left(\mathrm{NH}_{4}\right)_{2} \mathrm{SO}_{4}-25 ; \mathrm{CaCl}_{2} \times 2 \mathrm{H}_{2} \mathrm{O}-10 ; \mathrm{MgCl}_{2} \times 6 \mathrm{H}_{2} \mathrm{O}-5$; $\mathrm{NaCl}-200 ; \mathrm{NH}_{4} \mathrm{Cl}-200$; and $\mathrm{KH}_{2} \mathrm{PO}_{4}-200$, supplemented with a vitamin solution $(10 \mathrm{~mL})$ and a trace element solution $(10 \mathrm{~mL})$, was used as a basic mineral solution $(\mathrm{H}(-))$ [77]. The medium was prepared without addition of cysteine or other reducing agents, to facilitate assessment of the natural reduction potential of the investigated microbial communities. The hermeticity of the bottles (oxygen intrusion) was monitored chromatographically. No resazurin was added. The $\mathrm{pH}$ of the medium was adjusted to 7 with $\mathrm{KOH}$. The experimental treatments were prepared with tryptone, yeast extract, acetate, and $\mathrm{CO}_{2} / \mathrm{H}_{2}(20: 80 v / v)$ as shown in Table 5. The initial headspace pressure in $\mathrm{N}_{2}$-filled containers was close to atmospheric. In treatments with $\mathrm{CO}_{2} / \mathrm{H}_{2}$, nitrogen was replaced with a mixture of the given gases with overpressure of approximately $150 \mathrm{kPa}$ [78].

Table 5. Variants of the media.

\begin{tabular}{ccccc}
\hline Media code & Tryptone $\left(\mathbf{g ~ L}^{-\mathbf{1}}\right)$ & Yeast Extract $\left(\mathbf{g ~ L}^{-\mathbf{1}}\right)$ & $\mathbf{C H}_{\mathbf{3}}$ COONa $\left(\mathbf{g ~ L}^{-\mathbf{1}}\right)$ & Under $\mathbf{G a s e s}$ \\
\hline $\mathrm{SZN}$ & & Natural sediment with no additives & $\mathrm{N}_{2}$ \\
$\mathrm{H}(-) \mathrm{CO}_{2} / \mathrm{H}_{2}$ & 0 & 0 & 0 & $\mathrm{CO}_{2} / \mathrm{H}_{2}(20: 80 v / v)$ \\
$\mathrm{H}(-)$ acet & 0 & 0 & 0 & $\mathrm{~N}_{2}$ \\
$\mathrm{H}(+)$ & 0.5 & 0.5 & 0 & $\mathrm{~N}_{2}$ \\
$\mathrm{H}(+) \mathrm{CO}_{2} / \mathrm{H}_{2}$ & 0.5 & 0.5 & 2 & $\mathrm{CO}_{2} / \mathrm{H}_{2}(20: 80 v / v)$ \\
$\mathrm{H}(+)$ acet & 0.5 & 0.5 & $\mathrm{~N}_{2}$ \\
\hline
\end{tabular}

$\mathrm{H}(-)$ - basic mineral solution, $\mathrm{H}(+)$ - basic mineral solution supplemented with tryptone and yeast extract.

The enrichments were carried out in $120 \mathrm{~mL}$ serum vials in a 1:50 proportion of the inoculating material to the fresh medium in the dark and without shaking for up to 90 days. The bottom sediments were used as an inoculum in the first stage of the enrichment (S1), whilst the liquid enrichment from the previous stages (S1 and S2, respectively) were used in the second (S2) and third (S3) stages. Incubations of the SZN and S1 enrichment cultures were carried out at temperatures between 10 and $40{ }^{\circ} \mathrm{C}$. The number of temperature variants at subsequent stages was reduced by those characterized by the lowest methanogenic activities.

The optical density of the enrichment $\left(\mathrm{OD}_{660}\right)$ was measured using a UV-1800 (Shimadzu, Japan) spectrophotometer [79].

\subsubsection{Chromatographic Analyses and Calculation of the Methane Production}

The rate of $\mathrm{CH}_{4}$ production and, also loss of $\mathrm{CO}_{2}$ and $\mathrm{H}_{2}$ in some research enrichment variants, was determined using a gas chromatograph (GC 3800, Varian, USA) equipped with flame ionization (FID, $200{ }^{\circ} \mathrm{C}$ ) and thermal conductivity $\left(\mathrm{TCD}, 120^{\circ} \mathrm{C}\right.$ ) detectors in series and with the use of two types of columns: a Poraplot Q $0.53 \mathrm{~mm}$ ID $(25 \mathrm{~m})$ and a Molecular Sieve 5A $0.53 \mathrm{~mm}$ ID $(30 \mathrm{~m})$ connected together, were used with helium as the carrier gas [74,80]. Methane production rate (MP) was determined on the basis of the linear increase in the methane concentration in time and expressed as a mg of produced $\mathrm{CH}_{4}$ per litre of bottom sediments or enrichment medium per day $\left(\mathrm{mg} \mathrm{CH}_{4} \mathrm{~L}^{-1} \mathrm{~d}^{-1}\right)$.

\subsection{DNA Extraction and NGS Procedure}

Microbial genomic DNA from the bottom sediment and cultures was extracted using a PowerLyzer PowerSoil DNA Isolation Kit (Quiagen, Hilden, Germany) according to the manufacturer's instructions. $0.25 \mathrm{~g}$ of fresh material from the bottom sediments and cell pellets harvested from $4 \mathrm{~mL}$ of the enrichments (after centrifugation, $13000 \times \mathrm{RPM}, 5 \mathrm{~min}$ ) in the last incubation step (S3) were used for isolation. The presence of DNA was confirmed by electrophoresis in a $1 \%$ agarose gel with $1 \times \mathrm{TBE}$ buffer and a SimplySafe ${ }^{\mathrm{TM}}$ (EURX) stain for detection of nucleic acid. The V3-V4 region of 16S rRNA gene amplicons were sequenced with the MiSeq Illumina technology (Genomed Inc, Poland). 


\subsection{Bioinformatic Analysis}

Amplicon sequence variants (ASVs) were resolved with DADA2 version 1.8 package [81] in $R$ version 3.5.1 [82]. Based on the sequence quality plots, forward and reverse reads were trimmed, respectively, to 250 and $240 \mathrm{bp}$, and primer sequences were removed from all reads. The following filtering parameters were used: $\operatorname{maxN}=0$, $\operatorname{maxEE}$ for the forwards reads $=3$ and for the reverse reads $=5$, truncQ $=2$. Other parameters were set to default. The error rates were estimated by learnErrors using one million reads. Sequences were dereplicated using derepFastq with default parameters and exact sequence variants were resolved using dada. Next, removeBimeraDenovo was used to remove chimeric sequences.

Taxonomy was assigned against the latest version of the RDP database (11 version) using a Naïve Bayesian Classifier [83] with the minboot parameter set to 80. The resulting taxonomy and read-count tables constructed in DADA2 were appropriately converted and imported into the phyloseq (1.22.3) package [84]. Sequences identified as chloroplast and mitochondria were removed.

$16 \mathrm{~S}$ rRNA amplicon sequencing data generated in this study were deposited in the NCBI Sequence Read Archive (SRA) under the BioProject number PRJNA514232.

\subsection{Metabolic Pathways Prediction Using PICRUSt Software}

Using PICRUSt (Phylogenetic Investigation of Communities by Reconstruction of Unobserved States, software) [85], the functional genes were reconstructed based on bacterial 16S rRNA gene sequences. The input ASVs from the dada2 workflow were clustered into OTUs (operational taxonomic units) using the cluster-features-closed-reference algorithm implemented in qiime2 software [86] with the $97 \%$ similarity threshold and using the GreenGenes (13.8) database as a reference. The number of $16 \mathrm{~S}$ rRNA gene copies was normalized using the normalize_by_copy_number.py algorithm implemented in PICRUSt software. Metagenomes were predicted using the predict_metagenomes.py algorithm, and the functional genes were annotated in the KEGG database using the categorize_by_function.py algorithm.

\section{Conclusions}

The results obtained in this study show that our current understanding of microbial processes leading to degradation of organic matter to methane is still far from complete. We have shown that in addition to the already identified relations in the microbial world leading to methane production, there is an enormous scope of biotechnological potential hidden in the microbial "dark matter". In light of the great diversity and hardly graspable dynamics of microbial communities in the natural environment, our knowledge is still insufficient, although it is expanding year on year. In the present work, we have shown that the enrichment cultures diversified by the available carbon substrate may serve as a useful tool for the study of microbial ecology and physiology, giving a chance to highlight the activity of microorganisms (e.g., Caldisericum, Methanomassiliicoccus, Methanothrix) that escape recognition using other methods (e.g., based on pure culture analysis). Biotechnology can gain from studies of interspecies relations. Our research suggest that Caldisericum ssp., which are likely to cooperate with methanogens, may have an unexploited potential for the biogas production industry.

Furthermore, their high methane production rate and self-reduction capacity imply that further studies should be undertaken to test the potential of the cultures isolated from lake sediments for biogasification of various organic material. Furthermore, we suggested that more efforts should be made to investigate the role of Caldiserica in methane formation processes due to its putative positive impact that may have biotechnological application.

Author Contributions: Conceptualization, A.S.-N., A.P.; Investigation, A.S.-N., A.P., J.G., A.K. (Adam Kubaczyński), A.B., A.G. (Andrzej Górski); Formal analysis, A.S.-N., A.P., J.G.; Data curation, J.G., W.G., A.K. (Agnieszka Kuźniar); Methodology, A.S.-N., A.P., J.G.; Visualization, A.S.-N., A.P., J.G.; Writing-original draft preparation, A.S.-N., A.P.; Resources, A.G. (Anna Gałązka); Supervision, Z.S.; Funding acquisition, Z.S. Article revision, A.S.-N., A.P.

Funding: This research was funded by the National Science Centre (Poland), grant number 2015/17/B/NZ9/01662. 
Acknowledgments: We thank Magdalena Hunicz for her help in the laboratory work.

Conflicts of Interest: The authors declare no conflict of interest. The funders had no role in the design of the study; in the collection, analyses, or interpretation of data; in the writing of the manuscript, or in the decision to publish the results.

\section{Abbreviations}

KEGG Kyoto Encyclopedia of Genes and Genomes

PICRUSt Phylogenetic Investigation of Communities by

Reconstruction of Unobserved States, software

\section{References}

1. Boughner, L.A.; Singh, P. Microbial Ecology: Where are we now? Postdoc. J. 2016, 4, 3-17. [CrossRef] [PubMed]

2. Eckert, I.M.K.; Littlefair, J.E.; Zhang, G.K.; Chain, F.J.J.; Crease, T.J.; Cristescu, M.E. Bioinformatics for biomonitoring: Species detection and diversity estimates across Next-Generation Sequencing Platforms. Adv. Ecol. Res. 2018, 59, 1-32. [CrossRef]

3. Costessi, A.; van den Bogert, B.; May, A.; Ver Loren van Themaat, E.; Roubos, J.A.; Kolkman, M.A.B.; Butler, D.; Pirovano, W. Novel sequencing technologies to support industrial biotechnology. FEMS Microbiol. Lett. 2018, 365, fny103. [CrossRef] [PubMed]

4. Detman, A.; Mielecki, D.; Pleśniak, Ł.; Bucha, M.; Janiga, M.; Matyasik, I.; Chojnacka, A.; Jędrysek, M.-O.; Błaszczyk, B.K.; Sikora, A. Methane-yielding microbial communities processing lactate-rich substrates: A piece of the anaerobic digestion puzzle. Biotechnol. Biofuels 2018, 11, 116. [CrossRef] [PubMed]

5. Wang, S.; Hou, X.; Su, H. Exploration of the relationship between biogas production and microbial community under high salinity conditions. Sci. Rep. 2017, 7, 1149. [CrossRef] [PubMed]

6. Wojcieszak, M.; Pyzik, A.; Poszytek, K.; Krawczyk, P.S.; Sobczak, A.; Lipinski, L.; Roubinek, O.; Palige, J.; Sklodowska, A.; Drewniak, L. Adaptation of methanogenic inocula to anaerobic digestion of maize silage. Front. Microbiol. 2017, 8, 1881. [CrossRef] [PubMed]

7. Fuertez, J.; Boakye, R.; McLennan, J.; Adamsc, D.J.; Sparks, T.D.; Gottschalke, A. Developing methanogenic microbial consortia from diverse coal sources and environments. J. Nat. Gas Sci. Eng. 2017, 46, 637-650. [CrossRef]

8. Green, M.S.; Flanegan, K.C.; Gilcrease, P.C. Characterization of a methanogenic consortium enriched from a coalbed methane well in the Powder River Basin, U.S.A. Int. J. Coal Geol. 2008, 76, 34-45. [CrossRef]

9. Plugge, C.M. Biogas. Microb. Biotechnol. 2017, 10, 1128-1130. [CrossRef]

10. Rapheal, S.V.; Swaminathan, K.R.; Lalitha, K. Metabolic characteristics of an aerobe isolated from a methylotrophic methanogenic enrichment culture. J. Biosci. 2003, 28, 235-242. [CrossRef]

11. Enzmann, F.; Mayer, F.; Rother, M.; Holtmann, D. Methanogens: Biochemical background and biotechnological applications. AMB Expr. 2018, 8, 1. [CrossRef] [PubMed]

12. Evans, P.N.; Parks, D.H.; Chadwick, G.L.; Robbins, S.J.; Orphan, W.J.; Golding, S.D.; Tyson, G.W. Methane metabolism in the archaeal phylum Bathyarchaeota revealed by genome-centric metagenomics. Science 2015, 350, 434-438. [CrossRef] [PubMed]

13. Vanwonterghem, I.; Evans, P.N.; Parks, D.H.; Jensen, P.D.; Woodcroft, B.J.; Hugenholtz, P.; Tyson, G.W. Methylotrophic methanogenesis discovered in the archaeal phylum Verstraetearchaeota. Nat. Microbiol. 2016, 1, 16170. [CrossRef] [PubMed]

14. Purwantini, E.; Torto-Alalibo, T.; Lomax, J.; Setubal, J.C.; Tyler, B.M.; Mukhopadhyay, B. Genetic resources for methane production from biomass described with the Gene Ontology. Front. Microbiol. 2014, 5, 634. [CrossRef] [PubMed]

15. Conrad, R.; Klose, M.; Claus, P.; Enrich-Prast, A. Methanogenic pathway, C-13 isotope fractionation, and archaeal community composition in the sediment of two clear-water lakes of Amazonia. Limnol. Oceanogr. 2010, 55, 689-702. [CrossRef]

16. Lovley, D.R.; Klug, M.J. Model for the distribution of sulfate reduction and methanogenesis in freshwater sediments. Geochim. Cosmochim. Acta 1986, 50, 11-18. [CrossRef] 
17. Esteves, A.I.S.; Hardoim, C.C.P.; Xavier, J.R.; Gonçalves, J.M.; Costa, R. Molecular richness and biotechnological potential of bacteria cultured from Irciniidae sponges in the north-east Atlantic. FEMS Microbiol. Ecol. 2013, 85, 519-536. [CrossRef] [PubMed]

18. Zurita, G.; Pe'er, G.; Bellocq, M.I.; Hansbauer, M.M. Edge effects and their influence on habitat suitability calculations: A continuous approach applied to birds of the Atlantic forest. J Appl. Ecol. 2012, 49, 503-512. [CrossRef]

19. Kark, S. Effects of ecotones on biodiversity. In Encyclopedia of Biodiversity; Levin, S.A., Ed.; Elsevier Inc.: Amsterdam, The Netherlands, 2007; pp. 1-10.

20. Dabrowska-Prot, E.; Wasiłowska, A. Ecological importance of meadow patches in protected forest area: Floristic diversity and the dynamics of insect communities. Pol. J. Ecol. 2010, 58, 741-758.

21. Lachavanne, J.-B.; Juge, R. Biodiversity in Land-Inland Water Ecotones; Taylor \& Francis: Abingdon, UK, 1997; p. 326.

22. Shen, C.; Shi, Y.; Ni, Y.; Deng, Y.; Van Nostrand, J.D.; He, Z.; Zhou, J.; Chu, H. Dramatic increases of soil microbial functional gene diversity at the treeline ecotone of Changbai Mountain. Front. Microbiol. 2016, 7, 1184. [CrossRef]

23. Mieczan, T.; Adamczuk, M.; Tarkowska-Kukuryk, M.; Nawrot, D. Effect of water chemistry on zooplanktonic and microbial communities across freshwater ecotones in different macrophyte-dominated shallow lakes. J. Limnol. 2016, 75, 262-274. [CrossRef]

24. Jiang, H.; Dong, H.; Zhang, G.; Yu, B.; Chapman, L.R.; Fields, M.W. Microbial diversity in water and sediment of Lake Chaka, an athalassohaline lake in northwestern China. Appl. Environ. Microbiol. 2006, 72, 3832-3845. [CrossRef] [PubMed]

25. Laskar, F.; Das Purkayastha, S.; Sen, A.; Bhattacharya, M.K.; Misra, B.B. Diversity of methanogenic Archaea in freshwater sediments of lacustrine ecosystems. J. Basic Microbiol. 2018, 58, 101-119. [CrossRef] [PubMed]

26. Yang, S.S. Methane production in river and lake sediments in Taiwan. Environ. Geochem. Health 1998, 20, 245-249. [CrossRef]

27. Schwarz, J.I.K.; Eckert, W.; Conrad, R. Response of the methanogenic microbial community of a profundal lake sediment (Lake Kinneret, Israel) to algal deposition. Limnol. Oceanogr. 2008, 53, 113-121. [CrossRef]

28. Chan, O.C.; Wolf, M.; Hepperle, D.; Casper, P. Methanogenic archaeal community in the sediment of an artificially partitioned acidic bog lake. FEMS Microbiol. Ecol. 2002, 42, 119-129. [CrossRef] [PubMed]

29. Yang, Y.; Dai, Y.; Li, N.; Li, B.; Xie, S.; Liu, Y. Temporal and spatial dynamics of sediment anaerobic ammonium oxidation (Anammox) bacteria in freshwater lakes. Microb. Ecol. 2017, 73, 285-295. [CrossRef]

30. Rojas, P.; Rodríguez, N.; de la Fuente, V.; Sánchez-Mata, D.; Amils, R.; Sanz, J.L. Microbial diversity associated with the anaerobic sediments of a soda lake (Mono Lake, California, USA). Can. J. Microbiol. 2018, 64, 385-392. [CrossRef]

31. Ji, Y.; Angel, R.; Klose, M.; Claus, P.; Marotta, H.; Pinho, L.; Enrich-Prast, A.; Conrad, R. Structure and function of methanogenic microbial communities in sediments of Amazonian lakes with different water types. Environ. Microbiol. 2016, 18, 5082-5100. [CrossRef]

32. Huang, W.; Chen, X.; Jiang, X.; Zheng, B. Characterization of sediment bacterial communities in plain lakes with different trophic statuses. MicrobiologyOpen 2017, 6, e00503. [CrossRef]

33. Xing, L.; Yang, S.; Yin, Q.; Xie, S.; Strong, P.J.; Wu, G. Effects of carbon source on methanogenic activities and pathways incorporating metagenomic analysis of microbial community. Bioresour. Technol. 2017, 244, 982-988. [CrossRef] [PubMed]

34. Sinclair, L.; Osman, O.A.; Bertilsson, S.; Eiler, A. Microbial community composition and diversity via $16 \mathrm{~S}$ rRNA gene amplicons: Evaluating the illumina platform. PLoS ONE 2015, 10, e0116955. [CrossRef] [PubMed]

35. Wan, Y.; Ruan, X.; Zhang, Y.; Li, R. Illumina sequencing-based analysis of sediment bacteria community in different trophic status freshwater lakes. MicrobiologyOpen 2017, 6, e00450. [CrossRef] [PubMed]

36. Lan, G.; Li, Y.; Jatoi, M.T.; Tan, Z.; Wu, Z.; Xie, G. Change in soil microbial community compositions and diversity following the conversion of tropical forest to rubber plantations in Xishuangbanan, Southwest China. Trop. Conserv. Sci. 2017, 10, 1-14. [CrossRef]

37. Wu, X.; Xu, H.; Liu, G.; Ma, X.; Mu, C.; Zhao, L. Bacterial communities in the upper soil layers in the permafrost regions on the Qinghai-Tibetan plateau. Appl. Soil Ecol. 2017, 120, 81-88. [CrossRef]

38. Chen, Y.; Dai, Y.; Wang, Y.; Wu, Z.; Xie, S.; Liu, Y. Distribution of bacterial communities across plateau freshwater lake and upslope soils. J. Environ. Sci. 2016, 43, 61-69. [CrossRef] [PubMed] 
39. Parulekar, N.N.; Kolekar, P.; Jenkins, A.; Kleiven, S.; Utkilen, H.; Johansen, A.; Sawant, S.; Kulkarni-Kale, U.; Kale, M.; Sæbø, M. Characterization of bacterial community associated with phytoplankton bloom in a eutrophic lake in South Norway using 16S rRNA gene amplicon sequence analysis. PLoS ONE 2017, 12, e0173408. [CrossRef] [PubMed]

40. Jetten, M.S.M.; Stams, A.J.M.; Zehnder, A.J.B. Methanogenesis from acetate: A comparison of the acetate metabolism in Methanothrix soehngenii and Methanosarcina spp. FEMS Microbiol. Lett. 1992, 88, 181-197. [CrossRef]

41. Hubalek, V.; Buck, M.; Tan, B.; Foght, J.; Wendeberg, A.; Berry, D.; Bertilsson, S.; Eiler, A. Vitamin and Amino Acid Auxotrophy in Anaerobic Consortia Operating under Methanogenic Conditions. Msystems 2017, 2 , e00038-17. [CrossRef]

42. Fournier, G.P.; Gogarten, J.P. Evolution of acetoclastic methanogenesis in Methanosarcina via horizontal gene transfer from cellulolytic Clostridia. J. Bacteriol. 2008, 190, 1124-1127. [CrossRef]

43. Walker, C.B.; Redding-Johanson, A.M.; Baidoo, E.E.; Rajeev, L.; Hendrickson, E.L.; Joachimiak, M.P.; Stolyar, S.; Arkin, A.P.; Leigh, J.A.; Zhou, J.A.; et al. Functional responses of methanogenic archaea to syntrophic growth. ISME J. 2012, 6, 2045-2055. [CrossRef] [PubMed]

44. Wang, G.; Wang, D.I. Elucidation of growth inhibition and acetic acid production by Clostridium thermoaceticum. Appl. Environ. Microbiol. 1984, 47, 294-298. [PubMed]

45. Hugenholtz, P.; Pitulle, C.; Hershberger, K.L.; Pace, N.R. Novel division level bacterial diversity in a Yellowstone hot spring. J. Bacteriol. 1998, 180, 366-376. [PubMed]

46. Mori, K.; Yamaguchi, K.; Sakiyama, Y.; Urabe, T.; Suzuki, K. Caldisericum exile gen. nov., sp. nov., an anaerobic, thermophilic, filamentous bacterium of a novel bacterial phylum, Caldiserica phyl. nov., originally called the candidate phylum OP5, and description of Caldisericaceae fam. nov., Caldisericales ord. no. Int. J. Syst. Evol. Microbiol. 2009, 59, 2894-2898. [CrossRef] [PubMed]

47. Ma, T.-T.; Liu, L.-Y.; Rui, J.-P.; Yuan, Q.; Feng, D.-S.; Zhou, Z.; Dai, L.-R.; Zena, W.-Q.; Zhang, H.; Cheng, L. Coexistence and competition of sulfate-reducing and methanogenic populations in an anaerobic hexadecane-degrading culture. Biotechnol. Biofuels. 2017, 10, 207. [CrossRef] [PubMed]

48. Finster, K. Microbiological disproportionation of inorganic sulfur compounds. J. Sulfur. Chem. 2008, 29, 281-292. [CrossRef]

49. Loka Bharathi, P.A. Sulfur cycle. In Encyclopedia of Ecology; Jørgensen, S.E., Fath, B.D., Eds.; Academic Press: Oxford, UK, 2008; pp. 3424-3431.

50. Mori, K.; Sunamura, M.; Yanagawa, K.; Ishibashi, J.; Miyoshi, Y.; Iino, T.; Suzuki, K.; Urabe, T. First Cultivation and ecological investigation of a bacterium affiliated with the candidate phylum OP5 from hot springs. Appl. Environ. Microbiol. 2008, 74, 6223-6229. [CrossRef] [PubMed]

51. Stott, M.B.; Saito, J.A.; Crowe, M.A.; Dunfield, P.F.; Hou, S.; Nakasone, E.; Daughney, C.J.; Smirnova, A.V.; Mountain, B.W.; Takai, K.; et al. Culture-independent characterization of a novel microbial community at a hydrothermal vent at Brothers volcano, Kermadec arc, New Zealand. J. Geophys. Res. Solid Earth 2008, 113, B08S06. [CrossRef]

52. Monteux, S.; Weedon, J.T.; Blume-Werry, G.; Gavazov, K.; Jassey, E.J.; Johansson, M.; Keuper, F.; Olid, C.; Dorrepaal, E. Long-term in situ permafrost thaw effects on bacterial communities and potential aerobic respiration. ISME J. 2018, 12, 2129-2141. [CrossRef]

53. Martinez, M.A.; Woodcroft, B.J.; Ignacio Espinoza, J.C.; Zayed, A.A.; Singleton, C.M.; Boyd, J.A.; Li, Y.F.; Purvine, S.; Maughan, H.; Hodgkins, S.B.; et al. Discovery and ecogenomic context of a global Caldiserica-related phylum active in thawing permafrost, Candidatus Cryosericota phylum nov., Ca. Cryosericia class nov., Ca. Cryosericales ord. nov., Ca. Cryosericaceae fam. nov., comprising the four species Cryosericum septentrionale gen. nov. sp. nov., Ca. C. hinesii sp. nov., Ca. C. odellii sp. nov., Ca. C. terrychapinii sp. nov. Syst. Appl. Microbiol. 2019, 42, 54-56. [CrossRef]

54. Tiodjio, R.E.; Sakatoku, A.; Nakamura, A.; Tanaka, D.; Fantong, W.Y.; Tchakam, K.B.; Tanyileke, G.; Ohba, T.; Hell, V.J.; Kusakaba, M.; et al. Bacterial and archaeal communities in Lake Nyos (Cameroon, Central Africa). Sci. Rep. 2014, 4, 6151. [CrossRef] [PubMed]

55. Kurilkina, M.I.; Zakharova, Y.R.; Galachyants, Y.P.; Petrova, D.P.; Bukin, Y.S.; Domysheva, V.M.; Blinov, W.; Likhoshway, Y.V. Bacterial community composition in the water column of the deepest freshwater Lake Baikal as determined by next-generation sequencing. FEMS Microbiol. Ecol. 2016, 92, fiw094. [CrossRef] [PubMed] 
56. Dridi, B.; Fardeau, M.-L.; Ollivier, B.; Raoult, D.; Drancourt, M. Methanomassiliicoccus luminyensis gen. nov., sp. nov., a methanogenic archaeon isolated from human faeces. Int. J. Syst. Evol. Microbiol. 2012, 62, 1902-1907. [CrossRef] [PubMed]

57. Borrel, G.; Parisot, N.; Harris, H.M.B.; Peyretaillade, E.; Gaci, N.; Tottey, W.; Bardot, O.; Raymann, K.; Gribaldo, S.; Peyret, P.; et al. Comparative genomics highlights the unique biology of Methanomassiliicoccales, a Thermoplasmatales-related seventh order of methanogenic archaea that encodes pyrrolysine. BMC Genomics 2014, 15, 679. [CrossRef] [PubMed]

58. Chojnacka, A.; Szczęsny, P.; Błaszczyk, M.K.; Zielenkiewicz, U.; Detman, A.; Salamon, A.; Sikora, A. Noteworthy facts about a methane-producing microbial community processing acidic effluent from sugar beet molasses fermentation. PLoS ONE 2015, 10, e0128008. [CrossRef] [PubMed]

59. Liu, C.; Li, H.; Zhang, Y.; Si, D.; Chen, Q. Evolution of microbial community along with increasing solid concentration during high-solids anaerobic digestion of sewage sludge. Bioresour. Technol. 2016, 216, 87-94. [CrossRef]

60. Brugère, J.-F.; Borrel, G.; Gaci, N.; Tottey, W.; O’Toole, P.W.; Malpuech-Brugère, C. Archaebiotics: Proposed therapeutic use of archaea to prevent trimethylaminuria and cardiovascular disease. Gut Microbes 2014, 5, 5-10. [CrossRef]

61. Dridi, B.; Henry, M.; Richet, H.; Raoult, H.; Drancourt, M. Age-related prevalence of Methanomassiliicoccus luminyensis in the human gut microbiome. Apmis 2012, 120, 773-777. [CrossRef]

62. Bang, C.; Vierbuchen, T.; Gutsmann, T.; Heine, H.; Schmitz, R.A. Immunogenic properties of the human gut-associated archaeon Methanomassiliicoccus luminyensis and its susceptibility to antimicrobial peptides. PLoS ONE 2017, 12, e0185919. [CrossRef]

63. Kröninger, L.; Gottschling, J.; Deppenmeier, U. Growth characteristics of Methanomassiliicoccus luminyensis and expression of methyltransferase encoding genes. Archaea 2017, 2017, 2756573. [CrossRef]

64. Gorlas, A.; Robert, C.; Gimenez, G.; Drancourt, M.; Raoult, D. Complete genome sequence of Methanomassiliicoccus luminyensis, the largest genome of a human-associated Archaea species. J. Bacteriol. 2012, 194, 4745. [CrossRef] [PubMed]

65. Paul, K.; Nonoh, J.O.; Mikulski, L.; Brune, A. 'Methanoplasmatales,' Thermoplasmatales-related archaea in termite guts and other environments, are the seventh order of methanogens. Appl. Environ. Microbiol. 2012, 78, 8245-8253. [CrossRef] [PubMed]

66. Bowen De León, K.; Gerlach, R.; Peyton, B.; Fields, M. Archaeal and bacterial communities in three alkaline hot springs in Heart Lake Geyser Basin, Yellowstone National Park. Front. Microbiol. 2013, 4, 330. [CrossRef] [PubMed]

67. Lv, L.; Zhou, L.; Wang, L.-Y.; Liu, J.-F.; Gu, J.-D.; Mu, B.-Z.; Yang, S.-Z. Selective inhibition of methanogenesis by sulfate in enrichment culture with production water from low-temperature oil reservoir. Int. Biodeterior. Biodegrad. 2016, 108, 133-141. [CrossRef]

68. Söllinger, A.; Schwab, C.; Weinmaier, T.; Loy, A.; Tveit, A.T.; Schleper, C.; Urich, T. Phylogenetic and genomic analysis of Methanomassiliicoccales in wetlands and animal intestinal tracts reveals clade-specific habitat preferences. FEMS Microbiol. Ecol. 2016, 92, fiv149. [CrossRef] [PubMed]

69. Fan, X.; Xing, P. Differences in the composition of archaeal communities in sediments from sontrasting zones of Lake Taihu. Front. Microbiol. 2016, 7, 1510. [CrossRef] [PubMed]

70. Su, X.; Zhao, W.; Xia, D. The diversity of hydrogen-producing bacteria and methanogens within an in situ coal seam. Biotechnol. Biofuels 2018, 11, 245. [CrossRef] [PubMed]

71. LWB. Integrated Report of the Lubelski Wẹgiel BOGDANKA Capital Group for the Year 2016; Lubelski Węgiel Bogdanka SA: Lublin Voivodeship, Poland, 2017; pp. 122-134.

72. Ciosmak, M. The anthropogenic inundated area "Szczecin" in the zone of active underground exploitation of hard coal in the Lublin coal basin. J. Ecol. Eng. 2016, 17, 70-80. [CrossRef]

73. Sawicki, B. Geological and mining conditions of sublevel operation. In Proceedings of the 12th International Scientific and Technical Conference-Mining Natural Hazards, Katowice, Poland, 21-24 November 2005; The Central Mining Institute: Katowice, Poland, 2005; pp. 75-79. (In Polish).

74. Szafranek-Nakonieczna, A.; Steppniewska, Z. The influence of the aeration status (ODR, Eh) of peat soils on their ability to produce methane. Wetl. Ecol. Manag. 2015, 23, 665-676. [CrossRef] 
75. Banach, A.M.; Banach, K.; Visser, E.J.W.; Stępniewska, Z.; Smits, A.J.M.; Roelofs, J.G.M.; Lamers, L.P.M. Effects of summer flooding on floodplain biogeochemistry in Poland; implications for increased flooding frequency. Biogeochemistry 2009, 92, 247-262. [CrossRef]

76. Horn, M.A.; Matthies, C.; Küsel, K.; Schramm, A.; Drake, H.L. Hydrogenotrophic methanogenesis by moderately acid-tolerant methanogens of a methane-emitting acidic peat. Appl. Environ. Microbiol. 2003, 69, 74-83. [CrossRef] [PubMed]

77. Balch, W.E.; Fox, G.E.; Magrum, L.J.; Woese, C.R.; Wolfe, R.S. Methanogens: Reevaluation of a unique biological group. Microbiol. Rev. 1979, 43, 260-296. [PubMed]

78. Wolfe, R.S. Techniques for cultivating methanogens. Methods Enzymol. 2011, 494, 1-22. [CrossRef] [PubMed]

79. Stępniewska, Z.; Goraj, W.; Kuźniar, A.; Łopacka, N.; Małysza, M. Enrichment culture and identification of endophytic methanotrophs isolated from peatland plants. Folia Microbiol. (Praha) 2017, 62, 381-391. [CrossRef] [PubMed]

80. Szafranek-Nakonieczna, A.; Bennicelli, R.P. Ability of peat soil to oxidize methane and affect of temperature and layer deposition. Pol. J. Environ. Stud. 2010, 19, 805-810.

81. Callahan, B.J.; McMurdie, P.J.; Rosen, M.J.; Han, A.W.; Johnson, A.J.A.; Holmes, S.P. DADA2: High-resolution sample inference from Illumina amplicon data. Nat. Methods 2016, 13, 581-583. [CrossRef] [PubMed]

82. Development Core Team. A Language and Environment for Statistical Computing In R Foundation for Statistical Computing; R Development Core Team: Vienna, Austria, 2018; Available online: http://www.R-project.org (accessed on 10 June 2018).

83. Wang, Q.; Garrity, G.M.; Tiedje, J.M.; Cole, J.R. Naïve Bayesian classifier for rapid assignment of rRNA sequences into the new bacterial taxonomy. Appl. Environ. Microbiol. 2007, 73, 5261-5267. [CrossRef]

84. McMurdie, P.J.; Holmes, S. phyloseq: An R Package for Reproducible Interactive Analysis and Graphics of Microbiome Census Data. PLoS ONE 2013, 8, e61217. [CrossRef]

85. Langille, M.G.I.; Zaneveld, J.; Caporaso, J.G.; McDonald, D.; Knights, D.; Reyes, J.A.; Clemente, J.C.; Burkepile, C.E.; Thurber, R.L.V.; Knight, R.; et al. Predictive functional profiling of microbial communities using 16S rRNA marker gene sequences. Nat. Biotechnol. 2013, 31, 814-821. [CrossRef]

86. Bolyen, E.; Rideout, J.R.; Dillon, M.R.; Bokulich, N.A.; Abnet, C.; Al-Ghalith, G.A.; Alexander, H.; Alm, E.J.; Arumugam, M.; Asnicar, F.; et al. QIIME 2: Reproducible, interactive, scalable, and extensible microbiome data science. Peer] Preprints 2018. [CrossRef] 